\title{
Multiculturaliteit in het Belgische strafrecht
}

\author{
Luc Huybrechts*
}

\section{Multiculturaliteit en de rechtsorde}

De juridische aspecten van de multiculturele samenleving krijgen van langsom meer aandacht. In 2005 brachten prof. dr. M.C. Foblets en mr. S.W.E. Rutten daarover preadviezen uit voor de Nederlandse Vereniging voor Rechtsvergelijking. ${ }^{\mathrm{I}}$ Anderzijds gaf mijn collega raadsheer, prof. dr. E. Dirix, in 2007 een lezing over privaatrecht en multiculturaliteit, waarin hij terloops ook het culturele verweer in strafzaken aanraakte. ${ }^{2}$ En onlangs op vrijdag I3 juni 2008 - je moet maar durven debatteerde de Nederlandse Juristen-Vereniging over preadviezen van prof. dr. mr. W. van der Burg, prof. dr. mr. J.M. Schuyt en prof. mr. J.H. Nieuwenhuis betreffende de multiculturaliteit en het recht; ditmaal kwam specifiek het strafrecht ruim aan bod. ${ }^{3}$

'Cultuur' is een zwaar beladen term waarvan vele definities bestaan. ${ }^{4}$ Laten we het houden bij de definitie van de Universele verklaring van de Unesco betreffende culturele diversiteit. Deze beschouwt cultuur als een geheel van onderscheiden spirituele, materiële, intellectuele en emotionele kenmerken van de samenleving of van een maatschappelijke groepering; ze omvat naast kunst en literatuur ook levensstijlen, manieren van samenleven, waardensystemen, tradities en overtuigingen. ${ }^{5}$ En om onmiddellijk elke discussie tussen antropologen, criminologen en juristen de pas af te snijden: ik erken dat de betrekking tussen een enkeling en de samenleving of de maatschappelijke groepering waarmee hij een band heeft, altijd voor een stuk persoonlijk is, en beschouw evenmin cultuur of een culturele band als vaststaand en onveranderlijk maar steeds in meer of mindere mate in wording.

Dit gezegd, sedert het einde van de tweede wereldoorlog neemt de aanwezigheid van individuen en bevolkingsgroepen uit niet-westerse culturen, vooral van moslims maar niet alleen van hen, voortdurend toe. De hierdoor ontstane 'multiculturaliteit'

Luc Huybrechts is raadsheer in het Hof van Cassatie.

I. M.-C. Foblets en S.W.E. Rutten, Juridische aspecten van de multiculturele uitdagingen voor het beleid. Preadvies voor België. Kluwer, Deventer, 2005, respectievelijk: M.-C. Foblets, 'Juridische aspecten van de multiculturele samenleving. Knelpunten en uitdagingen voor het beleid', I-38; mr. S.W.E. Rutten, 'Cultuur en familirecht in eigen kring', 39-94.

2. E. Dirix, Privaatrecht en multiculturaliteit, Intersentia, Antwerpen-Oxford. 2007, 57 p.

3. Multiculturaliteit en Recht, Handelingen Nederlandse Juristen-Vereniging, Kluwer, Deventer, 2008, respectievelijk: W. van der Burg, 'Culturele diversiteit en de democratische rechtsstaat', I-6r; J.M. Schuyt, 'Publiekrecht in een multiculturele samenleving', 63-I23; J.H. Nieuwenhuis, 'Multicultureel recht: hoe is het mogelijk?', I25-I64.

4. Woordenboek filosofie, H. Willemsen (red.), Van Gorcum, Assen-Maastricht, I992, tw. 'Cultuur', 79-82.

5. www.unesco-vlaanderen.be/culturele_diversiteit/oo_inleiding.html. 
veroorzaakt soms samenlevingsproblemen die een zorg zijn voor de beleidsmakers. ${ }^{6}$ Multiculturaliteit vergt anderzijds een geleidelijke aanpassing van onze rechtsorde. ${ }^{7}$

De samenlevingsproblemen van de multiculturaliteit hebben een maatschappelijk debat op gang gebracht betreffende de 'normen en waarden' die individuen en maatschappelijke groeperingen in onze samenleving zouden moeten eerbiedigen en nastreven. Zo stelt het Eindverslag van mei 2006 van de door de Vlaams minister van Binnenlands Bestuur, Stedenbeleid, Wonen en Inburgering ingestelde 'Commissie ter invulling van de cursus maatschappelijke oriëntatie ${ }^{8}$, dat in onze multiculturele samenleving vijf hoofdvoorwaarden moeten worden vervuld: 'de vrijheid, de gelijkheid, de solidariteit, het respect, het burgerschap'; anderzijds zijn de stelsels van gemeenschappelijk waarden: 'de democratie, de democratische rechtsstaat en het pluralisme'. 9 Die hoofdvoorwaarden en stelsels van gemeenschappelijke waarden zijn onze 'hyperwaarden'. ${ }^{\text {IO }}$

Het preadvies gaat alleen maar na hoe cultuur een rol kan spelen in het strafrecht en het strafprocesrecht en dit enkel met de bedoeling een vergelijking tussen België en Nederland mogelijk te maken. Vooraleer dit aan te vatten wordt herinnerd aan het fundamentele mensenrecht op beleving van de eigen cultuur; het is inderdaad de bril waarmee wat volgt moet worden gelezen. Vervolgens komt het 'culturele misdrijf' aan bod. Dit wordt eenvoudig begrepen als het misdrijf waarbij cultuur op enigerlei wijze tussenkomt. Het gaat zowel om de strafbaarstellingen die de culturele vrijheid waarborgen als om strafbaarstellingen van bepaalde al of niet vreemde culturele gewoonten en gebruiken. Het zwaartepunt ligt evenwel op de volgende thema's van het culturele verweer en van de invloed van de culturele achtergrond op het vonnis van de strafrechter. Cultuur kan immers niet alleen tussenkomen bij het misdrijf en het verweer maar ook in het strafproces zelf. Dit laatste zal meteen het besluit zijn.

\section{Recht op beleving van de eigen cultuur}

De traditionele liberale fundamentele rechten en vrijheden van de Grondwet en de mensenrechtenverdragen waarborgen eenieder de vrije beleving van zijn cultuur, ook wanneer dit een vreemde cultuur is, voor zover evenwel de wet bepaalde gebruiken en gewoonten niet verbiedt en men geen inbreuk pleegt op de fundamentele rechten en vrijheden van anderen. De moderne sociale grondrechten waarborgen anderzijds eenieder het recht een menswaardig leven te leiden en zich cultureel te ontplooien. Bovendien genieten internationaal en supranationaal de minderheden

6. M.-C. Foblets, 'Juridische aspecten van de multiculturele samenleving. Knelpunten en uitdagingen voor het beleid', gecit., 38 .

7. $\quad$ E. Dirix, Privaatrecht en multiculturaliteit, gecit., 57 .

8. Ook genoemd 'Commissie Waarden en Normen' of 'Commissie Bossuyt'.

9. www.binnenland.vlaanderen.be/inburgering/offic\%EBIe\%2odocumenten/commissie\%2owaarden-normen/Eindverslag\%20Commissie\%2oWaarden\%2oNormen.pdf.

Io. Voor het begrip zie Charles Taylor, Bronnen van het zelf: de ontstaansgeschiedenis van de moderne identiteit, Lemniscaat, Rotterdam, 2007, hfdst. 3 'Onverwoorde ethiek', (vertaling van Sources of the self: The making of the Modern Identity, 1989). 
van langsom meer erkenning van het recht om hun eigen cultuur te beleven en taal te gebruiken.

\section{I Traditionele liberale fundamentele rechten en vrijheden}

De Grondwet verzekert de Belgen gelijkheid voor de wet (art. Io G.W.) en verbiedt discriminatie in het toekennen van het genot van de rechten en vrijheden (art. II G.W.); voorts waarborgt ze de burger fundamentele rechten en vrijheden die meteen de ruimte bieden waarbinnen hij vrij zijn eigen cultuur kan beleven. Zo garandeert ze: - de vrijheid van de eredienst en van meningsuiting, behoudens bestraffing van de misdrijven die bij het gebruik van die vrijheden worden gepleegd (art. I8 G.W.);

- $\quad$ het verbod van levensbeschouwelijke dwang (art. 20 G.W.);

- de vrijheid bij de inrichting van de eredienst met die beperking dat het burgerlijk huwelijk in beginsel altijd een huwelijkinzegening moet vooraf gaan (art. 2I G.W.);

- $\quad$ het recht op eerbiediging van het privé- en gezinsleven behoudens wettelijke uitzondering (art. 22 G.W.). ${ }^{\text {II }}$

Bijzonder is de bepaling dat het gebruik van de in België gesproken talen vrij is; dit gebruik kan niet worden geregeld dan door de wet en alleen voor handelingen van het openbaar gezag en voor gerechtszaken (art. 30 G.W.). Deze bepaling houdt verband met het feit op het grondgebied van het koninkrijk van oudsher Frans, Nederlands en zelfs Duits wordt gesproken. ${ }^{\text {I2 }}$

Iedere vreemdeling die zich op het Belgische grondgebied bevindt, geniet de bescherming verleend aan personen en aan goederen, behoudens de bij de wet gestelde uitzonderingen (art. I9I G.W.). Volgens het Grondwettelijk Hof laat de Grondwet tussen Belgen en vreemdelingen geen onderscheid toe dat volgens de criteria van de artikelen Io en II ervan niet redelijk en objectief verantwoord is. ${ }^{\mathrm{I} 3}$

Het Europees Verdrag van de Rechten van de Mens van 4 november 1950 en het verdrag van is december 1966 inzake burgerrechten en politieke rechten bevatten gelijkaardige fundamentele rechten en vrijheden als deze gewaarborgd bij de Grondwet. $^{\mathrm{I} 4} \mathrm{Ze}$ zijn evenwel zorgvuldiger omschreven dan in de Grondwet. Zo erkennen deze mensenrechtenverdragen:

- $\quad$ het recht op eerbiediging van privé-, familie en het gezinsleven (art. 8 EVRM en art. I7 IVBPR); ${ }^{\text {I5 }}$

II. Art. 22 van de G.W. werd slechts ingevoegd bij de wijziging aan de G.W. van 3 I januari I994.

I2. J.-J. Thonissen, La constitution Belge annotée, Bruxelles, Bruylant-Christophe, I979, 'article 23', nr. I39-I44.

I3. Arbitragehof nr. 6I/94, I4 juli 1994, www.arbitrage.be; A.A. I994, 775; B.S. 9 augustus I994, 20.I5I; J.L.M.B. I995, I396, noot D. Renders, 'La Cour d'arbitrage et l'article I9I de la Constitution'; J.T. I994, 673; Jaarboek Mensenrechten 1996-97, 283, noot; R.R.D. I994, 457; Rev. dr. étr. I994, 548 , noot J. Carlier, D. Vanheule, 'Les limites de l'égalité; l'arrêt n ${ }^{\circ}$ I/94 de la Cour d'arbitrage du I4 juillet I994'; T. Vreemd. I994, I79, noot M. van de Putte, 'Herfstnoot bij een zomers arrest'; TRD\&I I994, 729.

I4. M. Bossuyt, J. Wouters, Grondlijnen van internationaal recht, Intersentia, Antwerpen-Oxford, 2005.

I5. P. de Hert, Artikel 8 EVRM en het Belgisch Recht. De bescherming van privacy, gezin, woonst en communicatie, Mys \& Breesch, Gent, 1998. 
- de vrijheid van gedachte, geweten en godsdienst (art. 9 EVRM en art. I8 IVBPR);

- de vrijheid van meningsuiting (art. Io EVRM en art. I9 en 20 IVBPR);

- $\quad$ het recht van vergadering en vereniging (art. II EVRM en art. 2I en 22 IVBPR);

- $\quad$ het recht te huwen en een gezin te stichten volgens de nationale wetten (art. I2 EVRM en art. 23 IVBPR).

Terloops: al deze vrijheden kunnen onder bepaalde strikte voorwaarden worden beperkt; alleen voor het recht te huwen wordt geen beperking of uitzondering bepaald.

Art. I4 EVRM verbiedt, maar beperkt tot het genot van de rechten en de vrijheden in het verdrag vermeld, discriminatie 'op welke grond ook, zoals, geslacht, ras, taal, godsdienst, politieke of andere overtuiging, nationale of maatschappelijke afkomst, het behoren tot een nationale minderheid, vermogen, geboorte of andere status'. Art. 26 IVBPR heeft eenzelfde strekking. In zoverre deze bepalingen van het EVRM of het IVBPR kunnen worden ten uitvoer gebracht zonder tussenkomst van de wetgever, hebben ze rechtstreeks werking in de Belgische rechtsorde of, zorgvuldiger gezegd, kunnen ze worden toegepast zonder tussenkomst van de wetgever. ${ }^{16}$

Verbod van discriminatie verbiedt niet elk verschil in behandeling. Het Europees Hof voor de Rechten van de Mens ontwikkelde in de 'Belgische taalzaak' een aantal criteria daarvoor: ${ }^{17}$

- $\quad$ een verschil in behandeling van vergelijkbare situaties is pas in strijd met art. I4 EVRM als er voor het gemaakte onderscheid geen objectieve en redelijke verantwoording bestaat;

- $\quad$ het bestaan van een dergelijke verantwoording moet worden beoordeeld in het licht van het doel en de gevolgen van de betreffende maatregel, en rekening houdend met de in een democratische samenleving algemeen heersende principes;

- $\quad$ een onderscheid in de uitoefening van een bij het Verdrag vastgelegd recht moet een wettig doel nastreven;

- de aangewende middelen moeten kennelijk evenredig zijn t.a.v. het beoogde doel. ${ }^{\text {I8 }}$

\subsection{Moderne sociale grondrechten en recht op maatschappelijke en culturele ontplooiing}

De hierboven vermelde fundamentele rechten en vrijheden zijn de traditionele liberale grondrechten van het begin van de moderne tijd, einde $18^{\mathrm{e}}$ begin $19^{\mathrm{e}}$ eeuw. Men noemt ze ook 'de mensenrechten van de eerste generatie'. In de vorige eeuw is evenwel de

I6. M. Bossuyt, 'De inroepbaarheid van verdragsbepalingen of wat is er "rechtstreeks" aan de "rechtstreekse werking", in J. Wouters, D. van Eeckhoutte (eds.), Doorwerking van internationaal recht in de Belgische rechtsorde, Intersentia, Antwerpen-Oxford, 2006, III-II7.

I7. Hof Mensenrechten 23 juli I968 ('concerning to certain aspects of the Laws on the Use of Languages in Education in Belgium'), www.echr.coe.int; KIDS III, 3.3.I, 5; Publ. Eur. Court H.R. 1968, Serie A, nr. 6.

I8. G. Goedertier, G., '[E.V.R.M.] Artikel I4. Verbod van discriminatie', in In X., Handboek EVRM. Deel 2. Artikelsgewijze Commentaar, Deel 2, Volume II, editors: J. Vande Lanotte, Y. Haeck, Intersentia, Antwerpen, 2004, I27-I88, nr. 63. 
idee aangenomen dat naast die traditionele liberale grondrechten die de Staat verplichten zich te onthouden, de burger ook aanspraak kan maken op sociale 'grondrechten-vorderingen' die de Staat verplichten te doen. ${ }^{\text {I9 }}$

Om tegemoet te komen aan internationale verdragen erkent de Grondwet sedert een 20-tal jaar het recht om een menswaardig leven te leiden met alle daarvoor noodzakelijke rechten (art. 23 G.W.). ${ }^{20}$ Hiertoe behoort het recht op culturele en maatschappelijke ontplooiing. ${ }^{2 \mathrm{I}}$ In het recht om een menswaardig leven te leiden was inderdaad voorzien door internationale verdragen, zoals het Internationaal verdrag inzake economische, sociale en culturele rechten van ig december I966 (IVESCR), goedgekeurd in 1983 , en het Verdrag Europees Sociaal Handvest van I8 oktober I96I, goedgekeurd bij wet van ir juli ig9o.

Het door België goedgekeurde IVESCR heeft geen rechtstreekse werking in de interne rechtsorde. Het Grondwettelijk Hof heeft dit bevestigd. ${ }^{22}$ Toch verplicht het verdrag de Belgische Staat tot de langzame verwezenlijking ervan, minstens tot een 'standstill'. Onder dit laatste verstaat men de verplichting voor de wetgever geen afbreuk te doen aan reeds door de wetgeving gewaarborgde rechten. ${ }^{23}$ Een standstillverplichting is geen algemeen rechtsbeginsel, zoals het Hof van Cassatie in een strafzaak heeft gezegd. ${ }^{24}$ Er moet dus telkens nagegaan worden of dergelijke verplichting bestaat. ${ }^{25}$ Deze beperkende interpretatie die de sociale rechten slechts voorbehoudt voor vreemdelingen die regelmatig op het grondgebied verblijven, wordt in de rechtsleer betwist. ${ }^{26}$

Naast het IVESCR moet nog melding worden gemaakt van het kaderverdrag inzake de bescherming van nationale minderheden van de Raad van Europa, opgemaakt te Straatsburg op I november $1995 .{ }^{27}$ 'Nationale minderheden' doelt hier op

I9. L. Favoreu e.a., Droit des libertés fondamentales, $2^{\text {ème }}$ ed., Paris, Dalloz, nr. 32II-358.

20. Het huidige art. 23 G.W. dateert van enkele weken vóór de coördinatie van de G.W. van I994.

2I. R. Ergec, 'Introduction générale', in X., Les droits économiques, sociaux et culturels dans la Constitution, editor: R. Ergec, Collection de la Faculté de droit de l'Université libre de Bruxelles, Bruylant, Bruxelles, I995, I-I8.

22. Arbitragehof nr. 4/96, 9 januari 1996 (prejudiciële vraag), www.arbitrage.be; A.A. I996, 2I; B.S. 27 februari I996, 4I54; J.T. I996 (verkort), I88; Rev. dr. étr. I996, 27; T. Vreemd. I995, 389, noot L. Denys; T.B.P. I996 (verkort), 313; TRD\&I I996, afl. 4, I6.

23. G. Maes, 'Het standstillbeginsel in verdragsbepalingen en in art. 23 G.W.: progressieve (sociale) grondrechtenbescherming', R.W. 2005-06, I08I-I094 en www.rwe.be.

24. Cass. P.03.I3IO.F, I4 januari 2004, www.cass.be; J.L.M.B. 2004, I358 en http://jlmbi.larcier.be; Pas. 2004, 74, concl. J. Spreutels; R.W. 2005-06, 385 en www.rwe.be, noot L. Janssens, 'Het standstillbeginsel in het internationaal humanitair recht en de temporele werking van de strafwet'; Rev. dr. pén. 2004, 632, concl. J. Spreutels; Soc. Kron. 2004 (verkort), 506, concl. J. Spreutels, J., noot H. Mormont.

25. Bijv. Arbitragehof nr. I69/2002, 27 november 2002, www.arbitrage.be; A.A. 2002, 2023; A.P.M. 2002 (samenvatting), 224; B.S. I2 december 2002, 55.825 en staatsblad.be; J.L.M.B. 2003, I90 en jlmbi.larcier.be; Juristenkrant 2003 (weergave P. Vanden Heede), I3; NjW 2003, afl. 20, I62, noot S. d'Hondt; R.W. 2003-04, 93 en www.rwe.be; Rev. dr. étr. 2002, 618; T. Vreemd. 2003, 319, noot S. Bouckaert, 'De verplichte materiële dienstverlening aan kandidaat-vluchtelingen en de toets door het Arbitragehof aan het grondrechteninstrumentarium in het algemeen en aan het standstillbeginsel in het bijzonder'; T.B.P. 2003, 720; cf. ook J.-Fr. Leclercq, 'Sécurité sociale: stop ou encore?', J.T. 2007, 609-62I, inzonderheid nr. 2 -I2.

26. S. Bouckaert, Documentloze vreemdelingen. Grondrechten doorheen Belgische en internationale rechtspraak vanaf 1985, Maklu, Antwerpen-Apeldoorn, 2007, Deel 2: nr. 555 e.v.

27. http///66.I02.9.IO4/translate_c?hl=nl\&sl=en\&u=http://conventions.coe.int/Treaty/en/... 
traditioneel in een staat aanwezige minderheden. ${ }^{28}$ Dit neemt niet weg dat de inleidende overweging 'Gezien het feit dat het scheppen van een klimaat van verdraagzaamheid en dialoog nodig is om de culturele diversiteit als een bron en een factor, niet van splitsing, maar van verrijking voor elke samenleving' ook kan gelden voor de nieuwe minderheden. Nederland ratificeerde het kaderverdrag op i6 februari 2005; België heeft het daarentegen nog niet bekrachtigd. ${ }^{29}$ Dat België dit nog niet deed, houdt verband met de delicate culturele, gewestelijke en communautaire verhoudingen in het land (in de betekenis die deze in België hebben).

Ook het ontwerp van Europese Grondwet erkende de taal- en culturele verscheidenheid in Europa. ${ }^{30}$ Onnodig te zeggen dat de kwestie van de verscheidenheid van de in Europa gesproken talen daarbij zeer belangrijk is. ${ }^{3 \mathrm{I}} \mathrm{Na}$ het verdrag van Lissabon ${ }^{32}$ bepaalt art. 2 van de Geconsolideerde versie van het verdrag betreffende de Europese Unie:

'De waarden waarop de Unie berust, zijn eerbied voor de menselijke waardigheid, vrijheid, democratie, gelijkheid, de rechtsstaat en eerbiediging van de mensenrechten, waaronder de rechten van personen die tot minderheden behoren. Deze waarden hebben de lidstaten gemeen in een samenleving die gekenmerkt wordt door pluralisme, non-discriminatie, verdraagzaamheid, rechtvaardigheid, solidariteit en gelijkheid van vrouwen en mannen.'

\section{Anderzijds bepaalt art. 27 IVBPR:}

'In staten waar zich etnische, godsdienstige of linguïstische minderheden bevinden, mag aan personen die tot die minderheden behoren niet het recht worden ontzegd, in gemeenschap met de andere leden van hun groep, hun eigen cultuur te beleven, hun eigen godsdienst te belijden en in de prakrijk toe te passen, of zich van hun eigen taal te bedienen.'

Ook het Europees Sociaal Handvest erkent het recht op culturele en maatschappelijke ontplooiing als groep. 33

Ten slotte kan, ondanks de vrijheid van de beleving van de eigen cultuur en het gebruik van de eigen taal, van nieuwkomers kennis van de cultuur en de taal van het

28. D. Kurban, 'Substantive challenges tot the protection of religious freedom under the framework of the convention', in A. Verstichel, A. Alen, B. de Witte and P. Lemmens (eds), The Framework Convention for the Protection of National Minorities: a Useful Pan-European Instrument?, Intersentia, Antwerp Oxford - Portland, 2008, II9-I57, inzonderheid 2.2.I. 'National' Minorities.

29. http://conventions.coe.int/Traty/Commun/ChercheSig.asp.?NT=I57\&CM=\&DF=\&C...

30. J. Meeusen, 'De Europese G.W.: een nieuw institutioneel raderwerk voor een nieuwe Europese Unie?', in J. Meeusen en G. Straetemans (eds.), De Europese G.W.: troeven en tekorten, Intersentia, Antwerpen - Oxford, 2005, 62.

3I. P. Duparc Potier, 'La question des langues en Europe: entre paradoxes et divergences juridiques', Rev. trim. D.H. 2007, I05I-1085.

32. Verdrag van Lissabon tot wijziging van het Verdrag betreffende de Europese Unie en het Verdrag tot oprichting van de Europese Gemeenschap, ondertekend te Lissabon, I3 december 2007.

33. C. Javeau, 'Le droit à l'épanouissement culturel et social: quelques observations sociologiques', in R. Ergec e.a., Les droits économiques, sociaux et culturels dans la constitution, Bruylant, Bruxelles, I995, $273-284$. 
nieuwe vaderland worden vereist. De eisen die men hen stelt, moeten evenwel verenigbaar zijn met de G.W. en de mensenrechtenverdragen. ${ }^{34}$ Het Grondwettelijk Hof heeft die toets onlangs verricht op de zogenaamde Vlaamse wooncode, 35 die van nieuwe kandidaat-huurders vraagt dat ze bereid zijn Nederlands te leren. Tegen deze wooncode hadden onder meer de Franse Gemeenschapsregering en de vzw Liga voor Mensrechten beroepen tot nietigverklaring ingesteld. Op enkele details na doorstond de Vlaamse Wooncode de toets. ${ }^{36}$

\section{Strafbepalingen die culturele vrijheid waarborgen}

Sommige strafbepalingen betreffen rechtstreeks of onrechtstreeks de fundamentele rechten en vrijheden van individuen of groepen in verband met cultuur. Ze waarborgen in beginsel de vrije beleving van de eigen cultuur; soms leggen ze evenwel beperkingen of bijzondere regels op om de goede orde in de samenleving te vrijwaren. Het gaat om de strafbepalingen betreffende de vrije uitoefening van de erediensten, de voorrang van het burgerlijk huwelijk, het kanselmisdrijf, de daden van willekeur die inbreuk maken op door de Grondwet gewaarborgde vrijheden en rechten, de door racisme of xenofobie ingegeven daden, en tenslotte het geheim uit hoofde van zijn staat van de bedienaar van de eredienst. Enkele van die strafbepalingen zijn passé, terwijl andere nog actueel en soms zelfs betrekkelijk nieuw zijn.

\section{I Vrije uitoefening van de erediensten en vrijwaring van de andere door de Grondwet gewaarborgde rechten en vrijheden}

De art. I42 tot en met I46 Sw. voorzien een aantal wanbedrijven betreffende de uitoefening van de eredienst. Strafbaar worden gesteld: 37

- geweld of bedreiging inzake de uitoefening van een eredienst (art. I42 Sw.);

- verhinderen, belemmeren of onderbreken van een eredienst (art. I43 Sw.);

- beschimping van voorwerpen van de eredienst (art. I44 Sw.);

- $\quad$ smaad aan de bedienaar van een eredienst in de uitoefening van zijn bediening (art. I45, eerste lid, Sw.);

- $\quad$ slagen aan de aan de bedienaar van een eredienst in de uitoefening van zijn bediening (art. I45, tweede lid, en art. I46 Sw.).

Het begrip eredienst moet in brede zin worden verstaan. Het betreft elke eredienst, 'die naam waardig'. ${ }^{8}$ Of hij wettelijk erkend is of niet, doet er in feite niet toe. Zelfs deze die zelf de benaming eredienst of geloof afwijst, zoals bijvoorbeeld de getuigen van Jehova dat doen, blijft een eredienst; de enige beperking is dat erbij geen misdrij-

34. K. de Gucht, 'Inburgering door verplicht aanleren van de streektaal en de bescherming van de mensenrechten', T.B.P. I997, I5I-I59.

35. Decreet van I7 juli 1997 houdende de Vlaamse Wooncode, gewijzigd bij artikel 6 van het decreet van 15 december 2006.

36. G.W.telijk Hof nr. IoI/2008, ro juli 2008, www.arbitrage.be.

37. A. Marchal, J.P. Jaspar, Droit Criminel, Les infractions du code pénal, t. I, Larcier, Bruxelles, I975, nr. I25I69; A. de Nauw, Inleiding tot het bijzonder strafrecht, 5 ed., Kluwer, Mechelen, 2005, nr. I4.

38. Pandectes belges, T. 72, Larcier, Bruxelles, I902, 'Outrage envers les ministres d'un culte', nr. 7. 
ven worden gepleegd. ${ }^{39}$ De art. ${ }^{4} 2$ tot en met 146 Sw. beogen niet enkel de openbare orde maar vooral het door de Grondwet gewaarborgde recht van vrijheid van eredienst te vrijwaren. Ze willen uiteraard niet bepaalde geloofs- of levensbeschouwingen op zich te beschermen. ${ }^{4^{\circ}}$ Daarom is de beschimping van een geloofs- of levensbeschouwing zelf niet strafbaar gesteld. De mening daarover blijft inderdaad vrij, ${ }^{4 \mathrm{I}}$ of zoals een rechtbank onlangs vonniste, de meningsvrijheid omvat een recht op godlastering. ${ }^{42}$

De door de minister van Justitie ingestelde Commissie van wijzen die de problematiek van het statuut van de bedienaren van de erediensten en van de afgevaardigden van de Centrale vrijzinnige raad moest onderzoeken, stelt dat de hoger vermelde overbodige en, volgens haar, discriminatoire strafbepalingen best worden opgeheven. 43

\subsection{Voorrang van het burgerlijk huwelijk}

Art. 2I, tweede lid, G.W. bepaalt dat het burgerlijk huwelijk altijd de huwelijksinzegening moet voorafgaan; de wet mag evenwel van dit voorschrift afwijken. Art. 267, tweede lid, Sw. stelt anderzijds iedere bedienaar van een eredienst die een huwelijk inzegent vóór de voltrekking van het burgerlijk huwelijk strafbaar met een correctionele geldboete; die bepaling is evenwel niet van toepassing wanneer een van de personen die de huwelijksinzegening ontvangen hebben in levensgevaar verkeerde, en elk uitstel die plechtigheid onmogelijk had kunnen maken.

De strafbaarstelling van de inzegening van het religieuze vóór de voltrekking van het burgerlijke huwelijk houdt verband met het houden van de akten van de burgerlijke stand, opdracht die art. I64 G.W. aan de uitsluitende bevoegdheid van de gemeentelijke overheid heeft toevertrouwd. 44 Vandaag is het verschil in juridische gevolgen van, enerzijds, het huwelijk, anderzijds, andere samenlevingsvormen waarvoor geen gelijkaardige restrictie geldt, zeer klein geworden. De reeds vermelde Commissie van wijzen stelt dan ook voor art. 267, tweede lid, Sw. te schrappen, uiteraard onder de voorwaarde dat een godsdienstig huwelijk geen enkel burgerlijk gevolg heeft. 45

39. A. Marchal, J.P. Jaspar, Droit Criminel, Les infractions du code pénal, T. I, gecit., 52-63, inzonderheid nr. I27.

40. A. de Nauw, Inleiding tot het bijzonder strafrecht, gecit., nr. I4.

4I. Répertoire pratique du droit belge, Bruylant-Librairie générale du droit, T. III, gecit. tw. 'Cultes', nr. I3I-I34.

42. Corr. Brussel, 26 februari 2008, J.T. 2008, $35 \mathrm{I}$.

43. M. Magits, 'Erkende levensbeschouwingen. Commissie van wijzen herstelt deels de ongelijkheid', NjW 2006, 918-93I, inzonderheid nr. 2I.

44. A. Marchal, 'Crimes et délits contre l'ordre public commis par de fonctionnaires', in Novelles, Droit pénal, T. III, gecit., nr. 5048-5100, inzonderheid nr. 5059.

45. M. Magits, 'Erkende levensbeschouwingen. Commissie van wijzen herstelt deels de ongelijkheid', gecit., nr. $2 \mathrm{I}$. 


\subsection{Kanselmisdrijf}

Art. 268 Sw. bestraft met correctionele straffen de bedienaar van de eredienst die tijdens de uitoefening van zijn bediening in een openbare vergadering de regering, de wet, een koninklijk besluit of enige andere door de overheid van het openbaar gezag rechtstreeks aanvalt. Het misdrijf staat bekend als het 'kanselmisdrijf'. Die strafbaarstelling is de uiting van de in de in het midden van de $19^{\mathrm{e}}$ eeuw bestaande uitzonderlijke vrees voor de bedienaren van de eredienst. Het is inderdaad het misdrijf waaraan, merkwaardig genoeg, de toenmalige wetgever van het Strafwetboek de meeste aandacht heeft geschonken. ${ }^{46}$

De strafbepaling is al lang in onbruik gevallen. Ze is kennelijk niet verenigbaar met art. 9.2 EVRM. Ook zij zou best worden opgeheven. ${ }^{47}$ In elk geval blijven de openbare rechtstreekse uitlokking van een misdrijf (art. 66, laatste lid, Sw.), de smaad tegen een parlementair in de uitoefening of ter gelegenheid van de uitoefening van zijn mandaat, een minister, een magistraat of een officier van de openbare macht in actieve dienst of tegen elk ander drager van het openbaar gezag of tegen enig ander persoon met een openbare hoedanigheid bekleed (art. 275 en 276 Sw.) en laster en eerroof tegen een gesteld lichaam (art. $446 \mathrm{Sw}$.), op zich strafbaar.

\subsection{Daden van willekeur die inbreuk maken op door de Grondwet gewaarborgde vrijheden en rechten}

De ar. I47 tot 159 Sw. bestraffen daden van willekeur van ambtenaren die door de Grondwet gewaarborgd vrijheden en rechten schenden. Ze betreffen:

- de persoonlijke vrijheid (art. I47, I55, I56, I57, en I59 Sw.);

- de onschendbaarheid van de woning (art. I48 Sw.);

- de onschendbaarheid van het briefgeheim (art. I49 en I50 Sw.);

- de procedurevoorschriften voor de vervolging en de aanhouding van een minister of een senator (art. I58 Sw.)..$^{8}$

Art. I5I Sw. bestraft ten slotte elke andere daad van willekeur die inbreuk maakt op door de Grondwet gewaarborgde vrijheden en rechten en die bevolen of uitgevoerd wordt door een openbaar officier of ambtenaar, door een drager of agent van het openbaar gezag of van de openbare macht. Deze strafbaarstelling is een 'restcategorie' voor het geval geen andere strafbepaling de daad van willekeur strafbaar stelt. ${ }^{49}$

De strafbepalingen van de art. I48 tot $150 \mathrm{Sw}$. blijven toepasselijk ook wanneer het bevel niet uitgevoerd wordt. Anderzijds bestaat er voor de ondergeschikte een grond van rechtvaardiging wanneer hij handelde op bevel van zijn meerdere (art. I52 Sw.), en voor de meerdere wanneer zijn handtekening bij verassing is verkregen en hij de

46. A. Marchal, J.P. Jaspar, Droit Criminel, Les infractions du code pénal, T. I, gecit., nr. I405.

47. M. Magits, 'Erkende levensbeschouwingen. Commissie van wijzen herstelt deels de ongelijkheid', gecit., nr. 22.

48. A. Marchal, J.P. Jaspar, Droit Criminel, Les infractions du code pénal, T. I, gecit., nr. 15-20.

49. Cass. AR 9856, I8 november I992, www.cass.be; Arr. Cass. I99I-92, I317; Bull. I992, I269; Pas. I992, I, I269; cf. ook Brussel I2 maart I992, Rev. dr. pén. I993, 457, noot. 
daad die nog aan de gang is, deed ophouden en de schuldige aangaf (art. I53 Sw.). Wordt de daad van willekeur gepleegd door middel van de valse handtekening van een openbaar ambtenaar, worden de daders van de valsheid en zij die er kwaadwillig of bedrieglijk gebruik van maken, gestraft met opsluiting van io tot 15 jaar (art. I54 Sw.).

De door de wet bedoelde ambtenaren zijn de personen die door een middellijke of onmiddellijke delegatie volgend uit een wet, met een gedeelte van de overheidsmacht zijn bekleed. ${ }^{\circ} \mathrm{Er}$ is een inbreuk op door de Grondwet gewaarborgde rechten of vrijheden, wanneer de daad deze miskent en zij gepleegd wordt tegen de wil van de betrokken houder van die rechten of vrijheden. ${ }^{5 \mathrm{I}}$

'L'arbitraire est l'état d'esprit du fonctionnaire qui enfreint les devoirs de sa mission sociale par caprice, mauvaise volonté, par excès de zèle, sous l'effet d'une fausse conception de ses devoirs, par déformation professionnelle, égocentrisme ou par détachement dû à l'oubli progressif et à l'ignorance des servitudes de sa fonction, voire même sous l'effet d'une conception idéologique. ${ }^{52}$

Volgens de rechtspraak zijn inderdaad weerwraak, ${ }^{53}$ louter organisatorisch gemak, 54 een gril of een onverschoonbare zware fout, 55 daden van willekeur. De onwettigheid kan ook liggen in het motief van de ambtenaar. Zo is een stiptheidsactie een onwettig motief. ${ }^{56}$ Louter administratieve fouten zijn evenwel geen daden van willekeur. ${ }^{57}$

Verweer tegen een onwettelijke daad van de overheid is gerechtvaardigd wanneer de onwettelijkheid ervan klaarblijkelijk is. ${ }^{58}$ Dit is het geval wanneer de ambtenaar optreedt buiten de perken van zijn bevoegdheid 59 of handelt zonder dat aan een bepaalde bevoegdheid gevende formaliteit is voldaan. ${ }^{60}$ Verweer tegen een nietklaarblijkelijk onwettelijke daad is daarentegen niet gerechtvaardigd. ${ }^{6 \mathrm{I}}$ Ook wanneer het verweer buiten verhouding is met het aangedane onrecht, is er geen rechtvaardiging meer. ${ }^{62}$ Ten slotte dwingt de vaststelling dat de beklaagde in zekere mate

50. A. de Nauw, Inleiding tot het bijzonder strafrecht, gecit., nr. I5.

5I. A. Marchal, J.P. Jaspar, Droit Criminel, Les infractions du code pénal, T. I, gecit., nr. 299.

52. Législation Criminelle, T. II, I32, geciteerd in A. Marchal, J.P. Jaspar, Droit Criminel, Les infractions du code pénal, T. I, gecit., nr. 299.

53. I.v.m. een aanhouding voor ondervraging: Mons, 8 februari I99I, J.L.M.B. I99I, 923, noot P.M.; Rev. dr. pén. I99I, 984, noot C. de Valkeneer.

54. I.v.m. een aanhouding en het in de boeien slaan: Corr. Gent 23 november I998, T.G.R. I999, 35.

55. I.v.m. een aanhouding: Cass. 8300, 26 september I990, www.cass.be; Arr. Cass. I990-9I, 78; Bull. I99I, 72; Pas. I99I, I, 72; R.W. I99I-92, I86, noot B. Spriet, C. d'Haese, 'Het misdrijf van wederrechtelijke en willekeurige vrijheidsberoving'; Gent (6e k.) 2I december I999, T.G.R. - T.W.V.R. 2005,72 , noot.

56. Brussel I8 januari 1984, Pas. I984, II, 95; Rev. dr. pén. 1984, 602.

57. Brussel (rze k.) I3 oktober 2004, Amén. 2005 (weergave E. Orban de Xivry), i69.

58. Antwerpen 30 oktober I998, Limb. Rechtsl. I999, I54, noot J. Kerkhofs, [Weerspannigheid tegen 'onwettige' huiszoeking]; R.W. I999-00, 6ir en www.rwe.be, noot P. Arnou, 'Boswachters, zoeking in aanhorigheden en weerspannigheid'.

59. C. de Valkeneer, 'Le droit de poursuite sur le territoire d'un autre Etat contractant dans le cadre du traité d'extradition judiciaire Benelux et la résistance individuelle aux actes illégaux', noot onder Liège, I6 oktober I99I, Rev. dr. pén. I994, III.

6o. Antwerpen 6 juni I976, Pas. I976, II, 69 .

6I. Brussel 23 april I97I, J.T. I972, 228.

62. Corr. Turnhout 28 april I95I, R.W. I950-5I, I7I9. 
instinctief heeft gereageerd, de rechter nog niet aan te nemen dat hij zonder opzet heeft gehandeld of dat hij gedwongen werd door een macht hij niet kon weerstaan in de zin van art. 7I Sw. ${ }^{63}$

\subsection{Door racisme of xenofobie (vreemdelingenhaat) ingegeven daden}

De strijd tegen de toename van het racisme en de xenofobie is een bijzondere zorg van de Europese Unie. ${ }^{64}$ Men beschouwt het recht als het wapen bij uitstek daartegen. ${ }^{65}$ De wet van 30 juli I98I tot bestraffing van bepaalde door racisme of xenophobie ingegeven daden, ${ }^{66}$ zoals gewijzigd bij wet van 20 januari $2003,{ }^{67}$ stelde allerlei vormen van discriminatie strafbaar. De wet gaf ook aan het 'Centrum voor gelijkheid van Kansen en voor racismebestrijding' en aan bepaalde verenigingen met rechtspersoonlijkheid die zich tot doel stellen de rechten van de mens te verdedigen en de discriminatie te bestrijden, en ten slotte aan bepaalde representatieve organisaties, de bevoegdheid in rechte op te treden in de rechtsgeschillen betreffende de toepassing van de wet.

Net zoals bepaalde andere Belgische wetsbepalingen, stelt deze Antiracismewet ook grenzen aan de vrijheid van meningsuiting. ${ }^{68}$ De wet is inderdaad gericht tegen de politieke partijen die de grondrechten en vrijheden bedreigen. ${ }^{69}$ Het afbakenen van bepaalde grenzen aan de uitoefening van de rechten en vrijheden van de enen om de rechten en vrijheden van de anderen te vrijwaren, is ongetwijfeld een delicate evenwichtsoefening. ${ }^{70}$ Om terzake een doelmatige bestraffing te verzekeren, heeft de wet van 7 mei 1999 het art. I50 G.W. gewijzigd; de kennisneming van drukpers-

63. Cass. I7 augustus I978, Arr. Cass. I978, I, I290; Pas. I978, I, I256; cf. ook Corr. Luik 27 november 200I, Journ. proc. 2002, afl. 442, 28, noot J. Dermagne, 'La résistance aux abus de l'autorité'.

64. J. Flauss, 'L'action de l'Union européenne dans le domaine de la lutte contre le racisme et la xénophobie', Rev. trim. D.H. 200I, 487-5I5 ; X., L'Union Européenne et les Droits de l'Homme, verschillende bijdragen, I999.

65. X., 'Le droit face à la montée du racisme et de la xénophobie', verschillende bijdragen, Rev. trim. D.H. 200I, 265-688.

66. E. de Diesbach, 'La loi sur le racisme et la xénophobie', J.T. ı98I, 68I-682 ; B. Renson, 'Le racisme, la loi et l'opinion publique', Rev. dr. pén. I983, 727-753.

67. J. Mine, 'Chronique de législation pénale (année 2003)', Rev. dr. pén. 2004, 226-229; J. Mine, 'Chronique de législation pénale (année 2004)', Rev. dr. pén. 2005, 274; O. de Schutter, 'La loi belge tendant à lutter contre la discrimination', J.T. 2003, 845-856.

68. F. Roggen, 'Les limites juridiques à la liberté d'expression', in X., Liber Amicorum José Vanderveeren, Bruylant, Bruxelles, I997, I03-I40.

69. Zie X., Les partis liberticides et la Convention européenne des droits de l'homme, verschillende bijdragen, editor P. Lambert, reeks 'Droit et Justice', nr. 62, Nemesis - Bruylant, Brusxelles, 2005.

70. X., De Gordiaanse knoop van de antidemocratische partijen. De wet als tweesnijdend zwaard? Verschillende bijdragen, editors: A. Backs, S. Gutwirth, K. Leus, S. Baeten, Mys \& Breesch, Gent, $200 \mathrm{I}$. 
misdrijven die door racisme of xenofobie zijn ingegeven, is niet langer voorbehouden aan het hof van assisen. ${ }^{7 \mathrm{I}}$ Overigens wordt vandaag vaak niet door de drukpers maar via het internet aangezet tot racisme of xenophobie. ${ }^{72}$

De hoven en rechtbanken hebben reeds een aantal keren de Antiracismewet toegepast; ${ }^{73}$ onder meer ook de jeugdrechtbanken. ${ }^{74}$ Het Hof van Cassatie preciseerde dat aanzetten tot racisme of xenofobie niet vereist dat men 'openlijk' zijn wil te kennen geeft om aan te zetten tot dergelijke daden; het aanzetten op zich volstaat. ${ }^{75}$ Het hof zei ook dat de rechter die oordeelt over de voorlopige hechtenis, geen discriminatie bedrijft wanneer hij in feite vaststelt dat, onder meer, het objectief gegeven van de nationaliteit van de beklaagde mede een ernstige reden is om te vrezen dat hij zich aan het optreden van het gerecht zal onttrekken..$^{76}$ De zaak die het meest de aandacht heeft getrokken van het publiek en de commentatoren is de veroordeling door het Hof van Beroep te Gent van een aantal verenigingen rond het 'Vlaams Blok' wegens publicaties die aanzetten tot racisme of xenofobie. ${ }^{77}$ Het cassatieberoep tegen dit arrest werd verworpen..$^{8}$

Sedertdien werd de Antiracismewet opnieuw gewijzigd door de wet van ro mei 2007. ${ }^{79}$ Met uitzondering van de aangelegenheden die onder de bevoegdheid van de Gemeenschappen of de Gewesten vallen, is de wet zowel in de overheidssector als in de particuliere sector, met inbegrip van overheidsinstanties, op alle personen van toepassing met betrekking tot:

I. de toegang tot en het aanbod van goederen en diensten die publiekelijk beschikbaar zijn;

7I. V. Ost, 'Le raciste, le diffamateur et le nouvel article I50 de la Constitution', AM 2000, 27-35; A. Schaus, 'Les délits de presse à caractère raciste', in X., Pas de liberté pour les ennemis de la liberté' Groupements liberticides et droit, editors: H. Dumont, P. Mandoux, A. Strowel, F. Tulkens, Bruylant, Bruxelles, 2000, 33I-356.

72. Y. Poullet, 'La lutte contre le racisme et la xénophobie sur internet', J.T. 2006, 40I-4I2.

73. M. van de Putte, 'Wet Racisme en Xenophobie: 20 jaar rechtspraktijk', T. Vreemd. 200I, I89-20I.

74. P. Charlier, 'Chronique de jurisprudence: 1999 -200I, la loi du 30 juillet I $98 \mathrm{I}$ tendant à réprimer les actes inspirés par le racisme ou la xénophobie', J. dr. jeun. 2002, 7-17.

75. Cass. P.93.oIIo.F, I 19 mei 1993, www.cass.be; Arr. Cass. 1993, 514; Bull. 1993, 498, concl. J.M. Piret; F. Rechtspr. 1993, 3; J.T. 1993, 573, concl. Piret, noot; Journ. proc. 1993 (weergave), afl. 243, 31; Pas. I993, I, 498, concl. J.M. Piret; Rechtspraak Antiracismewet I999, I42; Rev. dr. pén. I993, 880; T. Vreemd. I993, I7I.

76. Cass. P.96.0090.N., 23 januari 1996, www.cass.be; Arr. Cass. 1996, 99; Bull. 1996, III; Pas. 1996, I, III; R.W. 1996-97, 537 en www.rwe.be; Rechtspraak Antiracismewet I999, I89.

77. Gent (8e k.) 2I april 2004, AM 2004, I70; J.T. 2004 (samenvatting), 590, noot E. Brems, S. van Drooghenbroeck, 'Le Vlaams Blok, groupement raciste. A propos de l'arrêt de la cour d'appel de Gand du 2I avril 2004'; Juristenkrant 2004 (weergave E. Brems), afl. 88, I; Juristenkrant 2004 (weergave C. van Vyve), afl. 9o, 5; Rev. b. dr. const. 2005, 553; T. Vreemd. 2004, I20, noot S. Sottiaux, D. de Prins, J. Vrielink, 'Het Vlaams Blok-arrest, artikel I5o van de G.W. en de interpretatie van de Antiracismewet'.

78. Cass. P.04.0849.N, 9 november 2004, AM 2005 (samenvatting), 74; www.cass.be; J.T. 2004, 856, noot; NjW 2005, 796; Pas. 2004, I745; C.D.P.K. 2005, 597, noot A. Vandaele, 'Het Hof van Cassatie tussen de hamer van de directe werking en het aambeeld van de prejudiciële vraagstelling'; J.D.S.C. 2006, I85, noot M. Delvaux; Rev. b. dr. const. 2005, 533; R.C.J.B. 2007 (verkort), 3I, noot J. van Meerbeeck, M. Mahieu; Rev. dr. pén. 2005, 789, noot M.-F. Rigaux, '[Racisme et xénophobie] Quand la Cour de cassation arbitre'; T.B.P. 2005, 43, noot F. Meersschaut, 'De ondraaglijke lichtheid van de G.W. [De verhouding tussen het Hof van Cassatie en het Arbitragehof]'.

79. S. Declercq, 'De bestrijding van discriminatie en de bestraffing van bepaalde door racisme of xenofobie ingegeven daden', TVW 2007, 282-284. 
2. de sociale bescherming, met inbegrip van de sociale zekerheid en de gezondheidszorg;

3. de sociale voordelen;

4. de aanvullende regelingen voor sociale zekerheid;

5. de arbeidsbetrekkingen;

6. de vermelding in een officieel stuk of in een proces-verbaal;

7. het lidmaatschap van of de betrokkenheid bij een werkgevers- of werknemersorganisatie of enige organisatie waarvan de leden een bepaald beroep uitoefenen, waaronder de voordelen die deze organisaties bieden;

8. de toegang tot en de deelname aan, alsook elke andere uitoefening van een economische, sociale, culturele of politieke activiteit toegankelijk voor het publiek. (art. 5, \$ I).

$\mathrm{Na}$ de gevallen en voorwaarden te hebben bepaald waarin het maken van onderscheid gerechtvaardigd is (art. 7 tot II), bepaalt de wet dat in de aangelegenheden die onder haar toepassingsgebied vallen, elke vorm van discriminatie verboden is, d.i. directe discriminatie, indirecte discriminatie, opdracht tot discrimineren en intimidatie (art. I2). De wet voorziet vervolgens wet uitgebreid in rechtsbescherming (art. I3 tot I8). Ze stelt verschillende feiten van discriminatie strafbaar met correctionele straffen (art. I9 tot 28), regelt de bewijslast in de gerechtelijke procedures met uitzondering van de strafrechtelijke procedures (art. 29 en 30) en verleent aan het Centrum voor gelijkheid van kansen en voor racismebestrijding en, onder bepaalde voorwaarden, aan zekere belangenverenigingen de bevoegdheid in rechte op te treden (art. 3i en 32).

\subsection{Geheim van staat van de bedienaar van de eredienst}

Art. 458 Sw. bestraft de personen die geheimen die hen uit hoofde van hun staat, ambt of beroep werden toevertrouwd, bekend maken buiten het geval dat zij geroepen worden om in rechte of voor een parlementaire onderzoekscommissie getuigenis af te leggen of de wet hen verplicht tot bekendmaking verplicht. ${ }^{80}$ Die wetsbepaling stelt evenwel niet alleen de schending van het geheim van zijn staat, ambt of beroep strafbaar - meestal spreekt men enkel van 'beroepsgeheim' - maar waarborgt ook de uitoefening van het door de wetsbepaling beschermde staat, ambt of beroep.

In afwijking van art. $458 \mathrm{Sw}$. verplicht art. $458 \mathrm{bis}$, ingevoegd bij wet 28 november 2000 betreffende de strafrechtelijke bescherming van minderjarigen, de personen met beroepsgeheim die hierdoor kennis hebben van één van de door wetsbepaling opgesomde geweld-, zeden- en nalatigheid- en onthoudingsmisdrijven gepleegd op een minderjarige, dit misdrijf ter kennis te brengen van de procureur de

8o. A. de Nauw, Inleiding tot het bijzonder strafrecht, gecit., nr. 322-338; D. Kigahane en Y. Pollet (Ed.), Le Secret professionnel, La Charte, Bruxelles, 2002; P. Lambert, Secret professionnel, Bruylant, Bruxelles, 2005; J. Leclercq, 'Secret professioinnel', in Novelles, Droit pénal, T. IV, Bruxelles, Larcier, I989; L. Huybrechts, 'Aspecten van het beroepsgeheim', in Strafrecht en strafprocesrecht, XXXIIe Postuniversitaire Cyclus Willy Delva 2005-06, Mechelen, Wolters Kluwer Belgium, 235-284. 
Konings. ${ }^{81,82}$ Deze verplichting geldt onverminderd de verplichtingen opgelegd door art. 422 bis Sw. betreffende het schuldig verzuim hulp te verlenen of te verschaffen aan iemand die in groot gevaar verkeert. De opheffing van de plicht tot geheimhouding is evenwel afhankelijk van drie cumulatieve voorwaarden:

- de persoon met beroepsgeheim moet het slachtoffer onderzocht of door het slachtoffer in vertrouwen zijn genomen;

- er moet een ernstig en dreigend gevaar bestaan voor de psychische of fysieke integriteit van het slachtoffer;

- $\quad$ en de persoon met beroepsgeheim deze integriteit niet zelf of met hulp van anderen kan beschermen.

Rechtsleer en rechtspraak hebben steeds het biechtgeheim van de katholieke priesters aanvaard. Vandaag erkent de rechtsleer ook de geheimhoudingsplicht van de bedienaren van alle erediensten - katholieke priesters, protestante dominees, joodse rabbijnen en mohammedaanse imamen - en van de levensbeschouwelijke lekenconsulenten, die wettelijk erkend zijn. ${ }^{83}$ Art. 458 Sw. laat de houder van een beroepsgeheim die als getuige onder eed wordt gehoord, te beslissen toch te spreken. Kerkjuristen maken evenwel een onderscheid tussen het engere biechtgeheim en het bredere beroepsgeheim. Zij menen dat een priester nooit en onder welk beding ook mag bekendmaken wat hij in de biecht heeft vernomen. ${ }^{84}$

\section{$4 \quad$ Strafbaarstellingen van culturele gewoonten en gebruiken}

Meerdere strafbepalingen betreffen te lande bestaande culturele gewoonten en gebruiken of bestraffen expliciet of impliciet vreemde culturele gewoonten en

8I. Het betreft de misdrijven omschreven in de artikelen 372 tot 377, 392 tot 394, 396 tot 405ter, 409, 423,425 en 426 Sw., dit zijn aanranding op de eerbaarheid en verkrachting, moord en opzettelijke doodslag, kindermoord, opzettelijke slagen en verwondingen met de dood tot gevolg en opzettelijk toebrengen van lichamelijk letstel, verminking van de genitaliën van een persoon van het vrouwelijk geslacht, verlaten of in behoeftige toestand achterlaten en het onthouden van voedsel onverminderd de verplichtingen hem opgelegd door artikel 422 bis.

82. P. Broeckx, M. Dumarey, R. Fock, 'Schuldig verzuim en beroepsgeheim in de context van strafrechtelijke bescherming van minderjarigen', in X., Strafrechtelijke bescherming van minderjarigen, Ed. G.Vermeulen, Maklu, Antwerpen, 200I, 436-487; A. de Nauw, 'De misdrijven van de Wet van 28 november 2000 betreffende de strafrechtelijke bescherming van minderjarigen', in X., De Praktijkjurist VI, Editor F. Moeykens, Academia Press, Gent, 2003, 4I-56; V. de Souter, 'Het beroepsgeheim en de invoering van een spreekrecht door de wet van 28 november 2000 betreffende de strafrechtelijke bescherming van minderjarigen. Een nadere analyse van het artikel $458 \mathrm{bis}$ van het Strafwetboek', T.J.K. 200I, I84-I92; M. Hirsch, N. Kumps, 'Secret professionnel et violence à l'égard des mineurs', in X., Le secret professionnel, Ed. D. Kiganahe, Y. Poullet, Reeks 'Droit en mouvement', La Charte, Bruxelles, 2002; 23I-250; F. Hutsebaut, 'De wet van 28 november 2000 betreffende de strafrechterlijke bescherming van minderjarigen: een overzicht', in X., Straf(proces)recht, Ed. L. Dupont, R. Verstraeten, F. Hutsebaut, Reeks 'Themis', nr. 6, Die Keure, Brugge, 200I, 8I-Io0; G.Vermeulen, F. Dhont, 'Bescherming van minderjarigen via het strafrecht. Verdiensten en beperkingen van de Wet van 28 november 2000 betreffende de strafrechtelijke bescherming van minderjarigen', T. Strafr. 2002, afl. 3, I24-I36; G. Vermeulen, 'Strenger en ook beter? Over de fragmentarische aanscherping van de strafrechtelijke bescherming van minderjarigen in de Wet van 28 november 2000', in X., Gandaius Actueel VII, Story-Scientia, Mechelen, 2002, I-27.

83. Bijv. P. Lambert, Secret professionnel, gecit., nr. 323-324.

84. P. de Pooter, 'Secret professionnel et secret de la confession', J.T. 2002, 20I-206. 
gebruiken. Het gaat bijvoorbeeld om de regeling van de begraafplaatsen en begravingen, de strafbaarstelling van het dubbel huwelijk of bigamie, de strafbaarstelling van het schijnhuwelijk en het gedwongen huwelijk, de strafbaarstelling van de genitale verminking van meisjes en vrouwen, de regels voor de rituele slachting en het politieverbod van de hoofddoek die onherkenbaar of niet-identificeerbaar maakt. Het hiernavolgende overzicht laat meteen een glimp zien van de ontwikkeling van bepaalde gewoonten en gebruiken in onze gewesten.

\section{I Begraafplaatsen en begravingen}

Begraafplaatsen en begravingen zijn belangrijke bestanddelen van een cultuur. Ze hebben in Europa en de westerse wereld sedert de middeleeuwen een lange evolutie doorgemaakt. ${ }^{85}$ Tot het einde van de $\mathrm{I}^{\mathrm{e}}$ eeuw waren ze uitsluitend een godsdienstige aangelegenheid. De Franse revolutie heeft ze geseculariseerd en toevertrouwd aan de gemeenten. ${ }^{86}$

Overeenkomstig ar. 77 B.W. mag geen teraardebestelling geschieden zonder een kosteloos verlof van de ambtenaar van de burgerlijke stand, die dit echter niet mag afgeven dan nadat hij zich naar de overledene heeft begeven om zich van het overlijden te vergewissen, en dit eerst 24 uren na het overlijden, behalve in de gevallen door de politieverordeningen bepaald. Art. 8o B.W. betreft de aangifte en vaststelling van overlijden in militaire of burgerlijke ziekenhuizen of in andere openbare inrichtingen.

Vanaf I januari 2002 zijn, bij toepassing van art. 6, § I, VII, $7^{\circ}$, van de bijzondere wet van 8 augustus I980 tot hervorming der instellingen, zoals vervangen door de bijzondere wet van I 3 juli 200 I houdende overdracht van diverse bevoegdheden aan de gewesten en de gemeenschappen, de gewesten bevoegd voor de materie van de begraafplaatsen en de lijkbezorging. ${ }^{87}$ In Vlaanderen regelt thans een decreet van de Vlaamse Raad van 16 januari 2004 de begraafplaatsen en de lijkbezorging. Overeenkomstig art. 6, § I, van het decreet mag alleen op gemeentelijke of intergemeentelijke begraafplaatsen worden begraven. Volgens art. $16, \S 2$, mag in bepaalde gevallen nog verder op bestaande particuliere begraafplaatsen worden begraven. Ten slotte bepaalt art. I6, § 3, dat afwijkingen van het bepaalde in $\S$ I kunnen worden toegestaan door de Vlaamse minister, bevoegd voor het gezondheidsbeleid, op voorstel van de burgemeester van de gemeente waar de begraving zal plaatshebben; hij mag de afwijking slechts toestaan op een op godsdienstige of filosofische overwegingen berustend verzoek, behalve als redenen van hygiëne en volksgezondheid dat niet toelaten. ${ }^{88}$ Volgens een ontwerp van besluit van de Vlaamse regering wordt voor de begraving rekening gehouden met uitvaartplechtigheden volgens de Katholieke,

85. Philippe Aries, L'homme devant la mort, Editions du Seuil, Paris, I977.

86. Répertoire pratique du droit belge, T. I, Bruylant-Librairie générale du droit, Bruxelles-Paris, I949, t.w. 'Cimetière', nr. 6.

87. Omzendbrief B.A. 2006/03 van ro maart 2006 betreffende de toepassing van het decreet van I6 januari 2004 op de begraafplaatsen en de lijkbezorging en de uitvoeringsbesluiten; www.binnenland.vlaanderen.be/regelgeving/omzendbrieven/omzIo.3.2006.htm.

88. Vgl. met wet van 20 juli I97I; A. de Wolf, 'Art. I6 Wet Begraafplaatsen en lijkbezorging', in X., Personen- en familierecht. Artikelsgewijze commentaar met overzicht van rechtspraak en rechtsleer, Kluwer, Mechelen, 4 . 
Protestantse, Anglicaanse, Orthodoxe, Joodse, Islamitische godsdienst en de Vrijzinnige of Neutraal filosofische overtuiging. ${ }^{89}$

Art. 315 Sw. straft met correctionele straffen zij die, zonder voorafgaand verlof van de openbare ambtenaar, een begraving verrichten of doen verrichten, en zij die op enigerlei wijze de wetten en verordeningen betreffende de begraafplaatsen en de vervoegde begravingen, dit is vóór 24 uren na het overlijden, overtreden. Deze wanbedrijven beteugelen de enkele materiële wetsovertreding..$^{\circ}$ Er bestaat nagenoeg geen rechtspraak over dit misdrijf.

Art. 453 Sw. straft met correctionele straffen hem die zich schuldig maakt aan grafschennis. ${ }^{9 \mathrm{I}}$ De zaak van de beklaagde die de gewoonte had ongevraagd binnendringen in mortuaria om aldaar foto's van hem onbekende kinderlijkjes te maken, heeft de rechtspraak toegelaten te preciseren dat grafschennis de opzettelijk gepleegde materiële daad is, niet alleen tegen het graf maar ook tegen de rustplaats van een overledene, waarbij zijn nagedachtenis wordt beledigd of gekwetst. ${ }^{92}$

Art. 526 Sw., ten slotte, straft met correctionele straffen onder meer kerkhofschennis, d.i. de vernieling, neerhaling, verminking of beschadiging van grafsteden, gedenktekens of grafstenen. Persberichten en internetzoekmachines leren dat grafen kerkhofschennis vrij vaak voorkomen. Het wordt meestal gepleegd uit vandalisme maar soms ook met de bedoeling wel bepaalde maatschappelijke groepen te beledigen en te kwetsen.

\subsection{Bigamie}

Het instituut 'huwelijk' behoort tot het culturele erfgoed van onze gewesten. Onder het 'ancien régime' was de echtverbintenis oorspronkelijk onverbreekbaar, een huwelijk tussen twee personen van hetzelfde geslacht gewoon ondenkbaar en een tweede huwelijk (bigamie) of een huwelijk van een man met meerdere vrouwen (polygamie) of een vrouw met meerdere mannen (polyandrie) absoluut uitgesloten. Het Napoleontische Burgerlijk Wetboek van 1804 handhaafde de fundamenten van het instituut, alhoewel echtscheiding mogelijk werd. 93 Evenwel kan sedert de wet van I3 februari 2003 tot openstelling van het huwelijk voor personen van hetzelfde geslacht en tot wijziging van een aantal bepalingen van het Burgerlijk Wetboek vandaag een huwe-

89. www.binnenland.vlaanderen.be/HRBB/dossiers/begraafplaatsen/begraafplaatsen/Besluit_wilsbeschikking_24febo6.doc

9o. J.S.G. Nypels, Le code pénal belge interprété, Bruxelles, Bruylant-Christophe, I867, T. I, ‘Art. 3I5’, nr. 2.

9I. P. Arnou, 'Graf- en kerkhofschennis', in X., Strafrecht en strafvordering. Artikelsgewijze commentaar met overzicht van rechtspraak en rechtsleer, Kluwer, Mechelen.

92. K.I. Antwerpen 3 juni I999, R.W. 2000-oI, I7 en www.rwe.be, noot P. Arnou, 'Grafschennis, het fotograferen van lijken en het betreden van mortuaria en funeraria'; cf. ook Cass. P.99.I034.N, 5 oktober 1999, www.cass.be; Arr. Cass. 1999, I223; Bull. I999, I274; R.W. 2000-oI (verkort), I4 en www.rwe.be, noot; T. Strafr. 2000, I4, noot J. Rozie, 'Grafschennis ruim bekeken'.

93. Cumulatieve editie van het burgerlijk wetboek, red. D. Heirbaut, G. Baeteman, Gent, 2004, XV, II2 en I94. 
lijk worden aangegaan tussen personen van hetzelfde geslacht. ${ }^{94}$ Het Grondwettelijk Hof heeft het beroep tot vernietiging van die wet verworpen. ${ }^{95}$ Het is duidelijk dat de invoering van het 'homoseksuele' huwelijk een ware culturele revolutie betekent. Het ook in andere Europese landen vandaag toegestane homoseksuele huwelijk kan implicaties hebben in landen wier cultuur of wetgeving het niet aanvaardt. $9^{6}$

Eerst iets over het burgerlijk recht. Art. I47 B.W. verbiedt een tweede huwelijk voor iedereen die nog door een vorig rechtsgeldig en niet-ontbonden huwelijk is verbonden. Het tweede huwelijk is absoluut nietig. ${ }^{97}$ Het verbod van 'bigamie' behoort tot de Belgische internationale openbare orde.$^{9} \mathrm{Er}$ kan dus in België geen tweede huwelijk worden gesloten ook niet door een man wiens nationale recht polygamie toelaat, 99 of - vandaag - door een vrouw wier nationale recht polyandrie toelaat. Toch verhindert het feit dat het Belgisch recht het tweede huwelijk verbiedt, niet dat in België bepaalde gevolgen van een in het buitenland gesloten tweede huwelijk worden erkend. Zo bepaalt art. 24, § 2, van het door België bij wet van 20 juli r970 goedgekeurd Algemeen Verdrag betreffende de sociale zekerheid tussen het Koninkrijk België en het Koninkrijk Marokko, ondertekend te Rabat op 24 juni I968, dat het weduwepensioen eventueel, gelijkelijk en definitief, verdeeld wordt onder de gerechtigden in de voorwaarden die zijn bepaald in het persoonlijk statuut van de verzoeker. ${ }^{\text {IOO }}$ De Belgische internationale openbare orde verhindert ook niet aan een in Marokko tussen Marokkanen rechtsgeldig en zonder bedrog gesloten tweede huwelijk beperkte gevolgen toe te kennen, zoals de bijstandsplicht en de plicht om bij te dragen in de kosten van het huishouden. ${ }^{\text {IOI }}$ Anderzijds heeft het Grondwettelijk Hof recent bepalingen van de Vreemdelingenwet vernietigd in zoverre ze kinderen uit een polygaam huwelijk uitsloten van het toepassingsgebied van art. Io dat van

94. K. Jansegers, 'Wet tot openstelling van het huwelijk voor personen van hetzelfde geslacht van I3 februari 2003', Tijdschrift@ipr.be 2003, 77-78 en www.ipr.be/nl_tijdschrift.html; G. Verschelden, 'De openstelling van het huwelijk voor personen van hetzelfde geslacht', TVW 2003, I48-I5I; G. Verschelden, 'Omzendbrief verduidelijkt wijzigingen ten gevolge van de invoering van het homohuwelijk', TVW 2003, 352-354; J. Renchon, 'L'ordre juridique belge: compétent universel?', Rev. trim. dr. fam. 2004, 259-263.

95. Arbitragehof nr. I59/2004, 20 oktober 2004, www.arbitrage.be; A.A. 2004, I83I; A.P.M. 2004 (samenvatting), afl. 9, 203; B.S. 29 oktober 2004 (tweede uitgave) (uittreksel), 74279 en http:// staatsblad.be; E.J. 2005, 22, noot P. Senaeve, 'Wet op het homohuwelijk niet strijdig bevonden met de G.W.'; J.T. 2005, 5I; Rev. trim. dr. fam. 2005, 408.

96. M. Pertegas Sender, 'Huwelijk tussen personen van hetzelfde geslacht in België: internrechtelijke en internationale implicaties', in X., De hervormingen in het personen- en familierecht 2002-2003, reeks 'Instituut voor Familierecht en Jeugdrecht K.U. Leuven', nr. 5, Intersentia, Antwerpen, 2003, 255280.

97. H. de Page, Traité élémentaire de droit civil belge, Bruylant, Bruxelles, I962, T. I ${ }^{\mathrm{er}}$, 3 ed., nr 6I4; H. Willekens, in X., Personen- en familierecht. Artikelsgewijze commentaar met overzicht van rechtspraak en rechtsleer, o.c., 'B.W. art. I47'.

98. N. Watte, 'Le fonctions de l'ordre public international et les droits de l'homme', in X., Mélanges John Kirkpatrick, Bruylant, Bruxelles, 2004, I047-I07I.

99. G. van Hecke, K. Lenaerts, Internationaal privaatrecht, A.P.R., E. Story-Scientia, Brussel, I989, nr. 459.

Ioo. Arbitragehof nr. 84/2005, 4 mei 2005 (prejudiciële vraag), www.arbitrage.be; A.A. 2005, I035; B.S. 7 juni 2005 (eerste uitgave) (uittreksel), 26252 en http://staatsblad.be; R.W. 2005-o6, afl. I9, 735, noot H. Storme, 'Arbitragehof vermijdt toetsing conflictenregel aan G.W.'; Soc. Kron. 2006 (samenvatting), afl. I, 55; Tijdschrift@ipr.be 2005, afl. 3, I9 en www.ipr.be/nl_tijdschrift.html.

IOI. Rb. Brussel (I4e k.) I8 december 200I, Rev. trim. dr. fam. 2004, 312, noot M. Fallon, [Mariage polygamique et ordre public atténué]. 
rechtswege verblijf in het Rijk toelaat (gezinshereniging). ${ }^{\text {I02 }}$ Ten slotte kunnen vreemde culturele opvattingen gewoon insijpelen in de toepassing van het bestaande recht. Zo heeft de 'Tribunal de Grande Instance de Lille' van I april 2008 een huwelijk van een islamitisch echtpaar nietig verklaard omdat de vrouw gelogen had over haar maagdelijkheid. Hierdoor was er volgens de rechtbank dwaling in de persoon of over de essentiële hoedanigheden van de persoon in de zin van artikel I8o, tweede lid, Franse Code Civil. ${ }^{\text {I03 }}$ De toepassing die de rechtbank hier van het Franse wets-

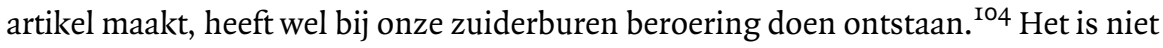
uit te sluiten dat ooit een Belgische rechter in dezelfde zin zou vonnissen. ${ }^{105}$

Van het burgerlijk recht naar het strafrecht nu. In de middeleeuwen waren overspel en tweede huwelijk ernstige misdrijven. Men beschouwde bigamie als een meineed en een verstoring van de maatschappelijke orde. Het tweede huwelijk was, enerzijds, een gemeenrechtelijk delict gericht tegen de orde van de familie en de burgerlijke staat van personen, anderzijds, een religieus delict wegens de opzettelijke en openlijke minachting van het sacrament van het huwelijk. ${ }^{\text {Io6 }}$

Vandaag bestraft art. 39I Sw. bigamie met opsluiting van 5 tot ro jaar. ${ }^{\text {I07 }}$ Het misdrijf vereist:

I. een eerste rechtsgeldig aangegaan en nog niet rechtsgeldig ontbonden huwelijk;

2. de voltrekking van een tweede huwelijk terwijl het vorige nog bestaat;

3. een strafbaar opzet bij de dader. ${ }^{\text {I08 }}$

Het vorige huwelijk moet rechtsgeldig zijn. Het bestaan ervan wordt bewezen door de overlegging van een uittreksel van huwelijksvoltrekking uit de registers van de burgerlijke stand (art. I96 B.W.). Indien bewezen wordt dat een rechtsgeldige akte heeft bestaan die vernietigd is, kan de strafrechter zelf het bestaan van het huwelijk vaststellen (art. I98 BW.). Een buitenlands huwelijk wordt bewezen door een overeenkomstig het recht van de staat waar zij is opgesteld, rechtsgeldige akte (art. 27,

I02. G.W.telijk Hof nr. 95/2008, 26 juni 2008, www.arbitrage.be, vernietiging van het artikel Io, § I, tweede lid van de wet van 15 december 1980 betreffende de toegang tot het grondgebied, het verblijf, de vestiging en de verwijdering van vreemdelingen, zoals vervangen bij artikel 6 van de wet van I5 september 2006, en vernietiging in artikel Io, \$ 2, vierde lid van dezelfde wet van de woorden 'en voor zover de aanvraag tot verblijf op basis van artikel ro werd ingediend in de loop van het jaar na beslissing tot erkenning van de hoedanigheid van vluchteling van de vreemdeling die vervoegd wordt', in zoverre die woorden van toepassing zijn op de in artikel Io, §I, eerste lid, $7^{\circ}$, van dezelfde wet van 15 december 1980 bedoelde minderjarige vreemdeling die als vluchteling werd erkend.

I03. Het Belgische art. I80 B.W. luidt (oorsronkelijk tweede lid: het eerste lid is ondertussen opgeheven bij art. 4 wet 25 april 2007, met ingang van 25 juni 2007) luidt: 'Wanneer er dwaling in de persoon heeft plaatsgehad, kan tegen het huwelijk alleen worden opgekomen door de degene van de echtgenoten die in dwaling werd gebracht.'

I04. http://blog.dalloz.fr/blodalloz/2008/06/de-la-virginit.html.

I05. H. Willekens, T. Wuyts, 'Art. I80 B.W', laatst bijgewerkt op I september I99I, in X., Personen- en familierecht. Artikelsgewijze commentaar met overzicht van rechtspraak en rechtsleer, Kluwer, Mechelen, nr. Io en II.

Io6. Code criminel de l'empereur Charles V, dit 'La Caroline', art. I2I; http://ledroitcriminel.free.fr/ la_legislation_criminelle/anciens_textes/la_caroline.htm.

I07. J.S.G. Nypels, Législation criminelle, T. III, Bruylant-Christophe et C ${ }^{\text {ie }}$, Bruxelles, I868, I42-I44.

I08. Pandectes belges, T. I3, Larcier, Bruxelles, I884, 'Bigamie'; A. Marchal, J.P. Jaspar, gecit., nr. III7-II23. 
§ I, wet I6 juli 2004 houdende het Wetboek van internationaal recht). Het kan in de praktijk erg moeilijk zijn te weten of te bewijzen dat een vreemdeling in het buitenland een vorig huwelijk heeft aangegaan. ${ }^{\text {I09 }}$

Bigamie vereist strafbaar opzet. Voor degene die reeds getrouwd is, bestaat dit opzet in de wetenschap dat zijn eerste huwelijk niet ontbonden is. Voor diegene die nog niet getrouwd was, bestaat ze in de wetenschap dat de persoon met wie hij een huwelijk aangaat nog verbonden is door een vorig huwelijk dat nog niet is ontbonden. Een goede bedoeling kan een verzachtende omstandigheid zijn maar is geen grond van rechtvaardiging. ${ }^{\text {IIO }}$ Zowel daders, als mededaders en medeplichtigen zijn strafbaar (art. 66 en 67 Sw.). Zo zijn strafbaar als mededader zowel de nieuwe echtgenoot die op het ogenblik van de huwelijksvoltrekking weet dat de persoon met wie hij in het huwelijk treedt, nog verbonden is door een vorig huwelijk, als die ambtenaar die het huwelijk voltrekt wetende dat een van de echtgenoten nog verbonden is door een vorig huwelijk. ${ }^{\text {III }}$ Inzake bigamie is in België de persoonlijke wet van de dader niet toepasselijk.

Daar in België het verbod van het tweede huwelijk tot de openbare orde behoort, is de Belgische wet toepasselijk op de vreemdeling in België, zelfs al laat de wet van zijn land van oorsprong polygamie toe. ${ }^{\mathrm{II} 2}$ Bigamie is een misdaad, zodat de poging ertoe strafbaar is (art. 52 Sw.).

Krachtens art. I van de Uitleveringswet van 15 maart I874, in zijn versie van vóór de vervanging ervan bij de wet van $3 \mathrm{I}$ juli 1985 , behoorde bigamie tot de bepaalde feiten waarvoor, overeenkomstig een op grondslag van wederkerigheid met een vreemde staat gesloten verdrag, een vreemdeling kon worden uitgeleverd. De toenmalige bilaterale verdragen vermeldden meestal bigamie onder de feiten waarvoor kon worden uitgeleverd. ${ }^{\mathrm{II} 3}$ Thans is overeenkomstig de huidige versie van art. I van de Uitleveringswet uitlevering op grond van een bilateraal of multilateraal verdrag mogelijk voor feiten die naar de Belgische en de buitenlandse wet strafbaar zijn met een vrijheidsstraf waarvan de maximumduur groter is dan één jaar. Art. 2.I van het Europees Verdrag betreffende uitlevering laat van zijn kant uitlevering toe voor onder meer feiten die krachtens de wetten van de verzoekende Partij en van de aangezochte Partij strafbaar zijn gesteld met een vrijheidsstraf met een maximum van ten minste een jaar of met een zwaardere straf. Anderzijds kan overeenkomstig art. 3 van de wet van I9 december 2003 betreffende het Europees aanhoudingsbevel dergelijk bevel worden uitgevaardigd wegens onder meer feiten die door de wet van de uitvaardigende Lid-Staat worden gestraft met een vrijheidsbenemende straf met een maximale duur van ten minste twaalf maanden.

De Belg of de persoon met hoofdverblijfplaats in het Rijk die zich buiten het Rijk schuldig maakte aan bigamie kan in België worden vervolgd indien op het feit straf is gesteld bij de wet van het land waar het tweede huwelijk werd voltrokken en op

I09. Les novelles, Droit pénal, T. III, gecit., tw. 'Crimes et délits contre l'ordre des familles et contre la moralité publique', nr. 6526.

IIo. J.S.G. Nypels, Le code pénal belge, T.II, gecit. 239, nr. 5 .

III. J.S.G. Nypels, Législation criminelle, gecit., 29-30.

II2. Répertoire pratique du droit belgen, T. I, gecit. tw. 'Bigamie', nr. 4.

II3. P.E. Trousse, J. Vanhalewijn, Uitlevering en internationale rechtshulp in strafzaken, A.P.R., Larcier, Brussel, I970, 93 e.v. 
voorwaarde dat de dader in België wordt gevonden (art. 7, § I, en I2, eerste lid, V.T.Sv.). Is de persoon met wie de dader een tweede huwelijk aanging een vreemdeling, dan kan de vervolging slechts plaatsvinden op vordering van het openbaar ministerie en moet zij bovendien voorafgegaan worden door een klacht van de benadeelde vreemdeling of van zijn familie ofwel door een officieel bericht, aan de Belgische overheid gegeven door de overheid van het land waar het misdrijf is gepleegd (art. 7, § 2, eerste lid, V.T.Sv.).

Een kwart eeuw geleden werden bigamie maar vooral overspel nog geregeld gestraft. ${ }^{\text {II } 4}$ Ondertussen heeft de wet van 20 mei 1987 tot opheffing van de art. 387 en $390 \mathrm{Sw}$. het overspel uit het strafrecht gehaald. De decriminalisering was het gevolg van de gewijzigde opvattingen over het huwelijk. Inbreuken op de huwelijkstrouw worden niet langer als een strafrechtelijke kwestie beschouwd. ${ }^{\text {II5 }}$ Anderzijds komt, beweert men, ingevolge de performante organisatie van de burgerlijke stand het afsluiten van een tweede huwelijk in België nog maar zelden voor. ${ }^{\mathrm{II}}$ De statistieken van het Nationaal Instituut voor de Statistiek maken zelfs geen melding meer van veroordelingen wegens bigamie. ${ }^{\text {II7 }}$

\subsection{Schijn- en gedwongen huwelijk}

In plaats van naar bigamie gaat vandaag de aandacht vooral uit naar de strijd tegen het 'schijnhuwelijk' en het 'gedwongen huwelijk'. Het eerste heeft feitelijk niets met cultuur te maken maar wel met vreemdelingen; het tweede houdt wel verband met cultuur maar misschien niet noodzakelijk vreemde culturen.

De wet van 4 mei 1999 tot wijziging van een aantal bepalingen betreffende het huwelijk wilde o.m. het schijnhuwelijk verhinderen. De strijd tegen het schijnhuwelijk is hoofdzakelijk toegespitst op vreemdelingen met louter verblijfsoogmerk. ${ }^{118}$ De bestrijding is zowel preventief als repressief, in de brede zin van het woord. ${ }^{\text {II } 9}$ Preventief kan de ambtenaar van de burgerlijke stand ofwel de voltrekking weigeren van een huwelijk dat naar zijn oordeel in strijd is met de beginselen van de openbare orde (art. I67, eerste lid, B.W.), ofwel indien er ernstig vermoeden van een schijnhuwelijk bestaat, de huwelijksvoltrekking ten hoogste twee maanden uitstellen teneinde een bijkomend onderzoek te verrichten (art. I67, tweede lid, BW.). Uiteraard voorziet de wet in een verhaal tegen de weigering van de huwelijksvoltrekking. Repressief kan het schijnhuwelijk worden nietig verklaard. Het Burgerlijk Wetboek bepaalt inderdaad dat er geen huwelijk is wanneer, ondanks de gegeven formele

II4. L. Verbiest, 'Bigamie en overspel. Overzicht van rechtspraak', Jura Falc. I980-8I, 323-344 en www.law.kuleuven.ac.be/jura.

II5. L. Stevens, Strafrecht en seksualiteit, De misdrijuen inzake aanranding van de eerbaarheid, verkrachting, ontucht, prostitutie, seksreclame, zedenschennis en overspel, Intersentia, Antwerpen, 2002, nr. 386.

II6. Betreffende Frankrijk : Ph. Bonfils, 'Bigamie', in Répertoire de droit pénal et de procédure pénale, Dalloz, Paris, octobre 2002, inzonderheid nr. Io.

II7. http://statbel.fgov.be.

II8. S. d'Hondt, 'Over schijn, zaken en schijnbare zaken. De geldigheid van het zakelijke huwelijk herafgewogen tegen de nietigheid van het schijnhuwelijk', R.W. 200I-02, I45-I53. Cf. ook S. d'Hondt, M. Foblets, 'De strijd tegen ontoelaatbare huwelijken: met welke middelen? Rechtspraakoverzicht - Twee jaar toepassing van de Wet van 4 mei I999', T. Vreemd. 2002, II5-I49.

II9. S. Lefebvre, 'Schijnhuwelijken, Preventie en repressie in een notendop', NjW 2007, 8I8-824. 
toestemmingen tot het huwelijk, uit een geheel van omstandigheden blijkt dat de intentie van minstens één van de echtgenoten kennelijk niet is gericht op de totstandbrenging van een duurzame levensgemeenschap, maar enkel op het verkrijgen van een verblijfsrechtelijk voordeel dat is verbonden aan de staat van gehuwde (art. I46bis B.W.). Anderzijds kan op grond van art. 27 van het Wetboek Internationaal Privaatrecht de Dienst Vreemdelingenzaken weigeren de buitenlandse huwelijksakte te erkennen of en de ambtenaar van de burgerlijke stand de huwelijksakte over te schrijven. Omdat ondanks deze maatregelen het aantal personen dat een schijnhuwelijk poogt te doen voltrekken blijft stijgen, werd door de wet van I2 januari 2006 een nieuw artikel 79bis ingelast in de Vreemdelingenwet dat het sluiten van een schijnhuwelijk, het ontvangen een geldsom daartoe, het gebruik van geweld om iemand ertoe te dwingen of poging tot een van die misdrijven strafbaar stelt. Sommigen zijn mening dat deze nieuwe strafbaarstelling niet echt nodig was, daar deze van valsheid in geschrifte of gebruik van valse of vervalste stukken volstond; ${ }^{120}$ anderzijds kan gebruik van valse of vervalste stukken ook ten laste worden gelegd tegen hem die in België een akte van een in het buitenland gesloten huwelijk voorlegt om hier een verblijfvoordeel te verkrijgen. ${ }^{\text {I2I }}$

Naast de strafbaarstelling van het schijnhuwelijk heeft de wet van 25 april 2007 tot invoeging van een artikel 39Isexies Sw. en tot wijziging van een aantal bepalingen van het Burgerlijk Wetboek met het oog op de strafbaarstelling en het uitbreiden van de middelen tot nietigverklaring van het gedwongen huwelijk de nietigheid en de strafbaarheid van het gedwongen huwelijk ingevoerd. Het Burgerlijk Wetboek bepaalt thans dat er evenmin een huwelijk is wanneer het wordt aangegaan zonder vrije toestemming van beide echtgenoten en de toestemming van minstens een van de echtgenoten werd gegeven onder geweld of bedreiging (art. I46ter B.W.). Anderzijds bestraft het nieuwe art. 39Isexies Sw. hem die iemand door geweld of bedreiging dwingt een huwelijk aan te gaan met gevangenisstraf I maand tot 2 jaar en met een geldboete van 50 tot 250 euro; poging wordt gestraft met I 5 dagen tot een jaar of met 50 tot 250 euro.

Het schijnhuwelijk mag niet verward worden met het 'gearrangeerd huwelijk' en het 'zakelijk huwelijk'. ${ }^{\mathrm{I22}} \mathrm{Bij}$ een gearrangeerd huwelijk hebben de aanstaande echtgenoten de keuze om al dan niet in het huwelijk te treden, maar het huwelijk zelf wordt georganiseerd door de beide families. Hierbij worden doorgaans subtiele dwangmechanismen aangewend die moeilijk te bewijzen zijn en bestempeld worden als sociaal aanvaardbaar, rekening houdend met de maatschappelijke structuren en de religieuze achtergronden van de betrokkenen. Een zakelijk huwelijk is ditgene waarbij men wel de intentie heeft om een levensgemeenschap aan te gaan, maar waarbij ook andere bedoelingen een rol spelen zoals het ontvluchten van armoede en eenzaamheid.

I20. P. Herbots, 'Nood aan specifieke wet voor strafbaarstelling schijnhuwelijk', Juristenkrant 2004, afl. 99, Io.

I2I. P. Herbots, E. Piatkowki, 'Federaal parket kan schijnhuwelijken gesloten in het buitenland vervolgen', Juristenkrant 2008, afl. I68, 4.

I22. C. Aerts, K. van Hoogenbemt, 'De strafrechtelijke beteugeling van het schijnhuwelijk, ingevoerd door de Wet van I2 januari 2006', E.J. 2006, 49-54, inzonderheid nr. 9 en ro. 


\subsection{Genitale verminking van meisjes en vrouwen}

De 'vrouwenbesnijdenis' of beter gezegd de verschillende vormen genitale verminking bij vrouwen, zijn oude en diepgewortelde Afrikaanse culturele gebruiken. ${ }^{123}$ Door de toenemende migratie werden ook de westerse landen met dit fenomeen geconfronteerd. Het roept hier bij velen een grondige afkeer op.

Volgens de rechtspraak van de Vaste Beroepscommissie maakt de genitale verminking van vrouwen een daad van vervolging 'wegens zijn ras, godsdienst, nationaliteit, het behoren tot een bepaalde sociale groep of zijn politieke overtuiging' uit in de zin van art. I, A, 2, van het Verdrag van 28 juli r95 I betreffende status van vluchteling, opgemaakte te Genève, waarvoor overeenkomstig art. 48/5, § 2, tweede lid, van

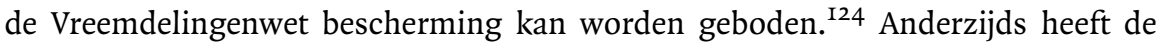
wetgever gewild genitale verminking ook te lande strafbaar te stellen. Daartegen werden argumenten aangevoerd die men vaak in het maatschappelijk debat over de multiculturaliteit hoort: een expliciete strafbaarstelling zal als een culturele vervolging aanvoelen; het getuigt van een armzalige opvatting van culturele integratie; men mag de vrouwen niet met dwang beschermen tegen hun eigen cultuur en sociale overtuigingen en men zal ze nog meer in de clandestiniteit jagen. ${ }^{125}$ Die tegenargumenten konden het parlement nochtans niet overtuigen.

De wet van 28 november 2000 betreffende de strafrechtelijke bescherming van minderjarigen heeft (opnieuw) een art. 409 ingevoegd in het Strafwetboek, dat genitale verminking bij meisjes en vrouwen zonder hun toestemming uitdrukkelijk strafbaar stelt. Voordien konden deze feiten naar gelang van de omstandigheden worden bestraft op grond van de art. 398, 399, 400, 40I of 40rbis Sw. ${ }^{126}$ Art. 409 Sw. bestraft hem die eender welke vorm van verminking van genitaliën van een persoon van het vrouwelijk geslacht uitvoert, vergemakkelijkt of bevordert met of zonder haar toestemming. ${ }^{127}$ De wetsbepaling heeft niet alleen betrekking op diegenen die de verminking uitvoeren, maar ook op diegenen die onder meer de verplaatsing naar het buitenland organiseren. De minderjarigheid van het slachtoffer is geen bestanddeel van het misdrijf, maar wel een verzwarende omstandigheid. Art. 409, § 2 tot 5, Sw. somt nog andere verzwarende omstandigheden op. Verminking van genitaliën wegens medische gronden zijn evenwel niet strafbaar. Ook transseksuele operaties vallen buiten het toepassingsveld van de wet. De vraag wordt geopperd waarom

I23. G. van Geertruyen, 'Vrouwelijke genitale verminking: de sociaal-culturele context', A.V.R.UG. - Afrika-Vereniging van de Universiteit Gent: http://cası.elis.rug.ac.be/avrug:vrouwelr.htm; zie ook M. Masclee, S. Meuwese, 'Genitale verminking bij meisjes en vrouwen', Ars Aequi (Ned.) 2000, 535-54I.

I24. Raad Vreemdelingenbetwistingen nr. 979, 25 juli 2007, Rev. dr. étr. 2007, 448, noot M. Ferrito, [Demande d'asile fondée sur la crainte de mutilations génitales].

I25. A. Dieruckx, Toestemming en strafrecht. Een strafrechtsdogmatische analyse van de toestemming en de strafrechtelijke bescherming van lijfen leven, Intersentia, Antwerpen, 2006, IIo e.v., nr. III.2.I.2.I.I.2.

I26. G. Vermeulen, F. Dhont, 'Bescherming van minderjarigen via het strafrecht. Verdiensten en beperkingen van de Wet van 28 november 2000 betreffende de strafrechtelijke bescherming van minderjarigen', T. Strafr. 2002, I24-136, inzonderheid 132.

I27. A. de Nauw, Inleiding tot het bijzonder strafrecht, gecit., nr. I69, I70 en 247. 
genitale verminking van meisjes en vrouwen uitdrukkelijk strafbaar werd gesteld, terwijl dat niet het geval is voor de besnijdenis van jongentjes. ${ }^{\text {I28 }}$

Inzake het misdrijf van art. 409 Sw. gelden dezelfde afwijkende regels voor de verjaring van de strafvordering en de toepassing van de wet in de ruimte als inzake de aanranding van de eerbaarheid en verkrachting. Overeenkomstig art. Ioter, $2^{\circ}$, V.T.Sv. kan eenieder in België vervolgd worden wanneer hij zich buiten het grondgebied van het Rijk schuldig maakt aan een van de misdrijven bepaald in de art. 372 tot $377 \mathrm{Sw}$. (aanranding van de eerbaarheid en verkrachting) en 409 Sw. (genitale verminking van meisjes en vrouwen). Overeenkomstig art. 2rbis, eerste lid, V.T.Sv. neemt de verjaring van de strafvordering slechts een aanvang van de dag waarop het slachtoffer de leeftijd van I8 jaar heeft bereikt en blijft daarenboven bij correctionalisering van de feiten de verjaringstermijn deze voor een misdaad.

\subsection{Rituele slachtingen}

De omgang met dieren behoort tot de culturele gewoonten en gebruiken van een maatschappij of een sociale groep. In de westerse wereld heeft de filosofische overtuiging ingang gevonden dat ook rechtvaardigheid is vereist voor niet-menselijke dieren. ${ }^{129}$ Sommigen staan daar erg kritisch tegenover. ${ }^{130}$ Eender hoe, in Nederland, zegt men, is de bescherming van het dierenwelzijn in opmars. ${ }^{13 \mathrm{I}}$ Men plaatst daar de fundamentele dierenrechten in zijn ruimere samenhang met de fundamentele rechten voor vrouwen, kinderen, homo's en van het milieu als ecosysteem. ${ }^{\mathrm{I}}{ }^{22} \mathrm{In}$ België genieten bepaalde voorvechters van dierenrechten ruime bekendheid. ${ }^{133}$

De rituele slachting van dieren is een cultureel gebruik bij joodse ultraorthodoxe en islamitische gelovigen. Art. 6, § I, van de wet van I4 augustus I986 betreffende de bescherming en het welzijn der dieren, bepaalt - onder strafdreiging (art. $\left.35, \mathrm{I}^{\circ}\right)$ - dat slachten slechts mag plaatshebben na bedwelming van het dier of, in geval van heirkracht, volgens de minst pijnlijke methode. Overeenkomstig § 2, kunnen de methoden van slachten en bedwelmen worden bepaald bij KB volgens de omstandigheden van het slachten en de diersoort. Dit KB kan bepalen dat sommige slachtingen voorgeschreven door de ritus van een eredienst moeten worden uitgevoerd in erkende slachthuizen of in inrichtingen erkend. Dit gebeurde bij het KB van II februari I 988 betreffende sommige door een religieuze ritus voorgeschreven slachtingen. Het is bijvoor-

I28. A. Dierickx, Toestemming en strafrecht. Een strafrechtsdogmatische analyse van de toestemming en de strafrechtelijke bescherming van lijf en leven, gecit., 5 .

129. Martha Nussbaum, Grensgebieden van het recht. Over sociale rechtvaardigheid, vertaald door P. Diderich en R. van Kappe, Ambo, Amsterdam 2006, (vertaling van: Frontiers of justice), hfdst. 6.

I30. C. Redgwell, 'Life, The Universe And Everything: A Critique of Anthropocentric Rights', in X., Human Rights Approaches to Environmental Protection, editors: A. Boyle, M. Anderson, Clarendon Press, Oxford, I996, 7I-87.

I3I. A. Freriks, 'Bescherming van dierenwelzijn in opmars?', Ars Aequi (Ned.) 2005, 446-450.

I32. X., Mensenrechten, dierenrechten, ecosysteemrechten. Opstellen over het toekennen van fundamentele rechten aan mannen, vrouwen, kinderen, dieren en de rest van de natuur, n.a.v. de studiedag 'Dragers van fundamentele rechten - ontwikkelingen en perspectieven', 9 oktober 1996 te Leiden, redactie J. Loof, P. Cliteur, Stichting NJCM-Boekerij, Leiden, I997.

I33. Zie de acties van de vzw GAIA (Global Actions in the interest of animals) www.gaia.be/ned/control.php?\&topgroupname=\&groupname=over_GAIA\&subgroupname=dit_is_gaia. 
beeld dan ook verboden runderen, schapen en geiten thuis te slachten ter gelegenheid van het Islamitisch offerfeest; aangezien thuisslachtingen verboden zijn, mag de overheid deze dan ook niet nader regelen, zoals de Stad Gent dit had gedaan. ${ }^{134}$

Art. I van voornoemd $\mathrm{KB}$ stelt dat de door een religieuze ritus voorgeschreven slachtingen van runderen, schapen en geiten slechts mogen plaatsvinden in een openbaar of in een particulier slachthuis of in erkende inrichtingen. Volgens art. 2 mag het slachten voorgeschreven door een religieuze ritus mag slechts geschieden: $I^{\circ}$ wat de Israëlitische ritus betreft: door offeraars die daartoe door het Centraal Israelitisch Consistorie van België zijn gemachtigd;

$2^{\circ}$ wat de Islamitische ritus betreft: door offeraars die daartoe door het representatief orgaan van de Islamieten in België zijn gemachtigd.

Particuliere rituele slachtingen thuis zijn strijdig met de voormelde bepalingen. ${ }^{\text {I35 }}$

Twee rechterlijke uitspraken zijn het noteren waard. De eerste betreft het recht op rituele slachtingen en de tweede het culturele element in de omgang met dieren. Volgens het Europees Hof van de Rechten van de Mens behoort de rituele slachting tot de mensenrechten gewaarborgd bij art. 8 EVRM. In Frankrijk mogen joodse rituele slachtingen enkel uitgevoerd worden door de daartoe erkende offerpriesters van de 'Association Consistoriale de Paris', die de meerderheid van de Franse joden verzamelt. Een joodse vereniging en haar leden voerden aan dat deze slachtingen niet voldeden aan bepaalde zeer strikte geloofsvoorschriften en dat de weigering hun een erkenning te verlenen art. 9 EVRM schendt. Het Europees Hof oordeelde evenwel dat het recht op vrijheid van godsdienst er niet kan toe leiden dat men een recht heeft om persoonlijk over te gaan tot rituele slachtingen en tot de hieruit voortvloeiende certificering. Het hof verwierp het verzoek omdat bleek dat verzoekster en haar leden concreet niet van de mogelijkheid waren verstoken om vlees te krijgen en te eten overeenkomstig hun religieuze voorschriften. ${ }^{136}$

De tweede uitspraak betrof het drinken van een kelk wijn met enkele levende blankvoorns, dit zijn zeer kleine visjes, op het zogenaamde 'krakelingenfeest' in Geraardsbergen. Voor het Hof van Beroep te Gent was de vraag gerezen of dit geen bij de art. I en $35, I^{\circ}$, van de wet van I4 augustus 1986 betreffende de bescherming en het welzijn der dieren verboden nutteloos doden van dieren is? Het hof oordeelde dat dit niet het geval is. Het feest dateert reeds uit de $\mathrm{I}^{\mathrm{e}}$ eeuw en heeft in cultuurhistorisch perspectief gezien nog een waardevolle finaliteit. Het doden van de visjes was dus niet nutteloos. Het Hof van Cassatie oordeelde van zijn kant dat de wet van I4 augustus I986 een cultuurhistorisch perspectief wel niet als een rechtvaardiging

I34. R.v.St. (I2e k.) nr. I63.475, I2 oktober 2006, www.raadvst-consetat.be; T. Gem. 2007, I40, noot.

I35. Kort Ged. Rb. Brussel nr. 03/998/B, Io februari 2003, Juristenkrant 2003 (weergave E. Brewaeys), afl. 65,5 .

I36. Hof Mensenrechten (Grote kamer) nr. 274I7/95, 27 juni 2000 (Cha'are Shalom Ve Tsedek / Frankrijk), www.echr.coe.int; J.T. dr. eur. 2000, I98; Juristenkrant 2000 (weergave E. Brems), afl. I5, I2; NJB (Ned.) 2000 (weergave), I676 en www.njb.nl; R.U.D.H. 2000, 247; R.W. 200 -02 (weergave H. Panken), 397 en www.rwe.be; Rev. trim. D.H. 200I, I85, noot Flauss, J. 'Abattage rituel et liberté de religion: le défi de la protection des minorités au sein des communautés religieuses'. 
beschouwt, maar ze de rechter evenmin verbiedt in bepaalde gevallen ermee rekening te houden. ${ }^{\mathrm{I}}{ }^{37}$

\subsection{Hoofddoek die onherkenbaar of niet-identificeerbaar maakt}

De polemieken rond de grondrechten en de multiculturaliteit kristalliseren zich vaak in hoofddoekendebat. Het is evenwel veel minder een strafrechtelijk probleem. In het strafrecht duikt het maar sporadisch op. Zo verbieden gemeentelijke politiereglementen, zoals bijvoorbeeld art. I68 van het politiereglement van Antwerpen, ${ }^{138}$ dat men zich in het openbaar zodanig kleedt dat men onherkenbaar of niet-identificeerbaar wordt. Dergelijke bepaling is wellicht wettig verantwoord door de eis van de openbare veiligheid. Eventueel zal de rechterlijke macht overeenkomstig art. I59 G.W. ambtshalve de wettelijkheid en dus ook de grondwettelijkheid van de politiereglementen toetsen, maar mag de wenselijkheid van een bepaling van een gemeentelijk politiereglement niet te beoordelen. ${ }^{\text {I39 }}$

Wanneer maakt een hoofddoek onherkenbaar of niet identificeerbaar? De omzendbrief van de minister van Binnenlandse Zaken van 7 oktober 1992 betreffende het houden van de bevolkingsregisters en het vreemdelingenregister kan hier wellicht als leidraad dienen. ${ }^{40}$ De omzendbrief bevat inderdaad voorschriften voor de foto op de identiteitskaart. Art. I5, hoofdstuk I, Afdeling III, bepaalt:

'Om een ontegenzeglijk godsdienstige of medische reden, kan een foto met hoofddeksel toegestaan worden, op voorwaarde dat het gezicht volledig vrij is, d.w.z. het voorhoofd, de wangen, de ogen, de neus en de kin moeten volledig vrij zijn. Het is wenselijk maar niet vereist dat het haar en de oren eveneens vrij zijn. Deze oplossing kan slechts aanvaard worden als de betrokken burger een ernstige rechtvaardiging voorlegt.

Er doen zich af en toe problemen voor met foto's waarop de persoon een sluier draagt. Er moet duidelijk worden gesteld dat de foto het mogelijk moet maken een persoon te identificeren en dat het gezicht dus niet gedeeltelijk verborgen mag zijn. Enkel om gerechtvaardigde medische of religieuze redenen, kan een foto met sluier worden toegestaan voor zover de essentiële elementen van het gezicht zichtbaar zijn.'

Een vonnis van I2 juni 2006 van de politierechter te Maaseik oordeelde dat het verbod van de stad Maaseik 'op het openbaar en het privaat domein van de overheid het gelaat

I37. Cass. P.02.0042.N, 5 november 2002, www.cass.be; Arr. Cass. 2002, 2357; NjW 2003, I260, noot G. Cazaux, 'Visjesdrinken op het krakelingenfeest in Geraardsbergen. Een cultuurhistorische finaliteit ter verantwoording van dierenleed?'; Pas. 2002, 2095; T. Strafr. 2003 , II6.

I38. www.antwerpen.be/INDEX/BED_NL/DOCS/STAD/BEDRIJVEN/INTEGRALE_VEILIGHEID/POLITIECODEX.PDF.

I39. Bijv. Cass. P.95.0497.N, 4 juni I996, www.cass.be; Arr. Cass. I996, 536; Bull. I996, 572; Pas. I996, I, 572.

I40. Cass. C.99.0I64.N, 22 december 2000, www.cass.be; A.J.T. 2000-oI, 596; Arr. Cass. 2000, afl. Io, 2088; Bull. 2000, afl. I2, 2042; J.T. 2003, 66; Juristenkrant 200I (weergave E. Brems), afl. 24, I4; T. Vreemd. 200I, 202, noot R. Verstegen, 'Een grondrecht beschermd bij rondzendbrief? Het Hof van Cassatie over de pasfoto met hoofddoek'. 
(...) te bedekken zodanig dat de identificatie van de persoon onmogelijk is. Het gelaat moet dus volledig vrij, onbedekt en voor iedereen zichtbaar zijn' wettig is. ${ }^{\text {III }}$

\section{$5 \quad$ Cultureel verweer}

Wanneer een partij in een strafproces een verweermiddel ontleent aan de culturele achtergrond van de zaak, spreekt men van 'Cultureel verweer'. Het is vooral een topic in de VSA. Ook in Nederland wordt er veel aandacht aan besteed.

\section{I 'Cultural defense' in de VSA}

Alison Dundes Renteln, professor in politieke wetenschappen en antropologie aan de University of South-Carolina, pleit in haar in 2004 uitgegeven boek 'The Culturel Defense' voor de invoering in de VSA van een formeel cultuur verweer. ${ }^{\mathrm{I}{ }^{2} 2}$ Dit pleidooi moet begrepen worden in de context van het Amerikaanse recht. Onnodig te zeggen dat dit soms fundamenteel verschilt van het Belgische.

Het formele culturele verweer bestaat erin dat de leden van etnische of ingeboren minderheidsgroepen de rechter kunnen vragen hun culturele achtergrond in aanmerking te nemen onder meer in strafzaken. Velen wijzen nochtans het formele culturele verweer af omdat het zou leiden tot anarchie. Etnische mindergroepen moeten zich maar aanpassen. Anderzijds zijn sommige rechters van mening dat iedereen moet voldoen aan eenzelfde maatstaf (de normen en waarden van de samenleving) en dat cultureel verweer niet ter zake doet. Cultureel verweer in aanmerking nemen betekent evenwel niet dat elke beklaagde vrijuit moet gaan of de eis van elke benadeelde moet worden toegewezen. Het betekent dat de strafrechter de culturele geboden en motieven van de partijen tracht te kennen en te begrijpen.

De culturele achtergrond is inderdaad een sterk motief bij het handelen. Om het te begrijpen en te beoordelen moet men die motieven kennen. Het culturele verweer is niet enkel een verdedigingsstrategie tegen de tenlastelegging van misdrijven, zoals moord en doodslag, mishandeling van dieren, brandstichting, omkoping, drugsmisdrijven, seksuele vergrijpen en vele andere. Culturele argumenten komen aan bod in de verschillende stadia van het strafproces, bijvoorbeeld bij de lijkschouwing. De culturele achtergrond kan ook een rol spelen bij de beslissing tot aanhouding of tot instelling van strafvervolging of bij de regeling van de rechtspleging. Ten slotte kunnen de beklaagden ten gronde een cultureel verweer opwerpen om een wettelijk bestanddeel van het misdrijf aan te vechten, de vrijspraak te bepleiten of niet-toerekeningsvatbaarheid of provocatie te doen aannemen.

Er worden verschillende argumenten pro en contra het culturele verweer in strafzaken aangevoerd. De aanvaarding ervan berust niet zozeer op de wens van culturele gevoeligheid of ontvankelijkheid ofschoon dit er zonder twijfel deel van uitmaakt, maar eerder op de wens een gelijke behandeling voor de wet te waarborgen voor alle

I4I. G. Geudens, 'Stad Maaseik mag boerka en niqaab verbieden. Politierechter spreekt zich uit over sluierkwestie', Juristenkrant 2006, afl. I37, I7.

I42. A.D. Renteln, The Culturel Defense, Oford, University Press, 2004, 'Introduction,' 5-9. 
burgers. Gelijkheid betekent hier niet alleen dat men alle zaken van culturele conflicten op een meer gelijke wijze behandelt maar ook dat men alle personen in de samenleving als gelijken tegemoet treedt. ${ }^{43}$ Het kernprobleem is soms de juridische maatstaf van 'een redelijk persoon' waaraan men het gedrag van een beklaagde toetst. $\mathrm{Nu}$ is net die redelijkheid vaak zelf de procesvraag. Men toetst de vereiste redelijkheid dan ook best aan de maatstaf van 'een redelijk persoon van een bepaalde cultuur in de context van die cultuur'. Zo bereikt men een juist evenwicht in de conflicterende eisen van de maatschappelijke orde en die van de wet. Dit kan onder meer door cultureel verweer als een verzachtende omstandigheid te aanvaarden. Het zal tezelfdertijd toelaten de doelen van het bestraffen te bereiken, nl. afschrikking, wederaanpassing en/of vergelding. Het aannemen van cultureel verweer overbrugt de kloof tussen het wettelijke opzetvereiste en het motief van de dader. Het laat ook toe tegemoet te komen aan de eis van proportionaliteit. Het aannemen van cultureel verweer heeft daartoe zijn plaats zowel bij de beoordeling van de schuld als bij de beslissing over de straftoemeting.

Als voornaamste tegenargument voeren de tegenstanders de afschrikking aan. Het cultureel verweer ondermijnt zowel de algemene als de bijzondere afschrikking; het zal op de duur het ganse rechtssysteem aantasten. Een ander argument is dat het aannemen ervan nadelig is voor kwetsbare groepen, zoals vrouwen en kinderen. Anderzijds is gelijkheid de gelijkheid voor de wet. Cultureel verweer brengt ongelijkheid in hoofde van de slachtoffers. Het bevordert ook de stereotypen van ongelijkheid. Het is bovendien moeilijk de grens te trekken tussen wat kan worden getolereerd en wat niet. Cultureel verweer kan tenslotte gemakkelijk leiden tot allerlei misbruik.

Men kan volgens Renteln die argumenten contra echter weerleggen. Ze zijn vooral op afschrikking gegrond. Het effect van afschrikking is evenwel ten zeerste betwistbaar. Het aannemen van cultureel verweer is bovendien maar aanvaardbaar voor zover het gedeeltelijk is. Het aannemen van verzachtende omstandigheden in een bepaalde strafzaak zal het algemeen strafrechtelijk systeem niet aantasten. Er is tenslotte geen feitelijk bewijs van enige anarchie. Het is ook niet waar dat cultureel verweer vaak wordt aangevoerd tegen zwakkere groepen. Verzachtende omstandigheden worden aangenomen in velerlei andere gevallen.

\subsection{Cultureel verweer in Nederland}

In Nederland heeft men blijkbaar al meer onderzoek gedaan en nagedacht over cultureel verweer dan in België. Een belangrijke studie is ongetwijfeld het doctoraal proefschrift van 2006 van Mirjam Siesling, Multiculturaliteit in strafzaken. ${ }^{\text {I44 }} \mathrm{Zij}$ onderzoekt de verdediging in culturele strafzaken. Hierna wordt haar doctoraatsthesis snel samengevat in korte stellingen.

Met de komst van migranten hebben vijf antropologische fenomenen hun intrede gedaan in de Nederlandse samenleving, in de eerste plaats de 'eer' en de 'schaamte' en

I43. A.D. Renteln, gecit., I85 e.v.

144. M. Siesling, Multiculturaliteit en verdediging in strafzaken. Een onderzoek naar de manieren waarop in het Nederlandse strafrecht ruimte wordt gevonden voor het verwerken van de culturele achtergrond van de verdachte, Boom Juridische uitgevers, Den Haag, 2006. 
de 'eer- en bloedwraak' of het 'eergerelateerd geweld', twee gerelateerde verschijnselen. ${ }^{45}$ Afhankelijk van de desbetreffende cultuur gaat het om de eer in de zin van aanzien, prestige en waardigheid, en/of de eer in de zin van eerbaarheid en kuisheid in het seksuele gedrag. Er is soms niet veel vereist voor een aantasting van de eer. De eerschending kan leiden tot eerwraak, dit is geestelijk of lichamelijk geweld gepleegd vanuit een collectieve mentaliteit in een reactie op de schending of de dreiging van de schending van de eer van een man of vrouw en daarmee van zijn of haar familie waarvan de buitenwereld op de hoogte is of dreigt te geraken. Het kiezen voor een gewelddadige oplossing voor het herstellen van de eer is een 'ultimum remedium'. Liever wordt gekozen voor een of andere vorm van bemiddeling, bijvoorbeeld een huwelijk van het meisje met de eerschender. De eerwraak is vaak niet een spontane onderneming maar wordt meestal voorafgegaan door een bepaalde vorm van overleg tussen de familie. Bloedwraak is de benaming voor een vete die heerst tussen twee of meer groepen personen (meestal familie) en waarbij via een proces van wederkerigheid ('oog om oog, tand om tand') groepsleden worden gedood (bijv. 'vendetta'). De aanleiding voor dergelijke vete kan liggen in een erekwestie, maar dat hoeft niet per se. Een bloedwraak is geen uitbarsting van eenvoudig of spontaan geweld, maar wordt beheerst door specifieke formaliteiten, procedures en regels. ${ }^{\text {I46 }}$

'Winti' en 'voodoo' zijn twee andere antropologische verschijnselen. Winti is een religie of levenschouwing die voorkomt in Suriname. Winti's zijn goden of geesten die het heelal beheersen. Zij kunnen van een mens bezit nemen, zowel in goedaardige als in kwaadaardige zin. Een medicijnman of ziener is evenwel in staat een verbinding te leggen tussen de mensen en de goden of genezingsrituelen te verrichten. Volgens het wintigeloof is iemand niet aansprakelijk voor wat hij doet tijdens een trance. Voodoo wordt aangehangen door het grootste gedeelte van de bevolking in Haïti. Door middel van een voodooritueel en het bezit van voodoopakjes met daarin lichaamseigen materiaal van de slachtoffers krijgt men iemand in zijn macht. Ook hier zij er priesters die de rituelen kennen. Deze bestaan ondermeer in de gewelddadige uitdrijving van de kwade geesten. Terloops: winti en voodoo zijn in de Belgische rechtspraak nagenoeg onbekend. Alleen in een oplichtingszaak was er sprake van voodoo. ${ }^{\mathrm{I}} 47$

Meisjes- of vrouwenbesnijdenis of vrouwelijke genitale verminking - het vijfde antropologisch verschijnsel - is een praktijk die vooral voorkomt in de zogenaamde Hoorn van Afrika (zie hoger). Zij wordt meestal uitgevoerd door iemand die geen lid is van de familie. Er is wel sprake van uitdrukkelijk goedkeuring door de familie. Door de besnijdenis wordt men volwaardig lid van de familie. Besneden zijn staat voor kuisheid en maagdelijkheid en onbesneden vrouwen kunnen uit hun familie of stamverband worden gestoten.

Een cultureel delict geeft maar een culturele strafzaak als ze zo wordt geconstrueerd. Het zijn de betrokkenen bij het strafproces - politie, tolk, deskundige, open-

I45. Wegwijzer eergerelateerd geweld, Interventieteam Relationele Druk en Geweld, Drukkerij Zuidzam \& zonen, Woerden, 2006.

I46. Zie ook M. Siesling, J.M. ten Voorde, 'Eerwrak in het Nederlandse strafrechtelijke beleid: een paradox van goede bedoelingen', Panopticon 2008.3, 7-28.

I47. Cass. 4 december 1979; Arr. Cass. I979-80, 4I6; Pas. I980, I, 4I6; R.W. I980-8I, 62, noot. 
baar ministerie, rechter, beklaagde en benadeelde - die de strafzaak kunnen construeren of medeconstrueren als een culturele strafzaak. De verdediging kan er evenwel belang bij hebben het culturele aspect achterwege te laten of af te zwakken, dan wel juist het aan te voeren of te benadrukken. De verdediging in een culturele strafzaak moet alert zijn. Vier factoren kunnen een beperkend effect hebben op een effectieve verdediging:

- de manier van communiceren in de rechtszaal (de ongelijke machtsposities en het onbegrijpelijke juridisch jargon); ${ }^{\mathrm{I} 48}$

- het gebrek aan tolken en soms de werkelijke of vermeende onbetrouwbaarheid van de tolk; ${ }^{\text {i49 }}$

- het veelvuldige ontkennen door bepaalde allochtonen;

- de beperkte budgetmiddelen van de verdediging.

Culturele verweren kunnen worden onderscheiden in 'cognitief-verweer' en 'niet-vrijewil-verweer'. Het cognitieve verweer betreft de onwetendheid van de dader die nog maar kort in het land is en de wet nog niet heeft kunnen kennen. Het 'niet-vrijewilverweer' gaat ervan uit dat de beklaagde het strafbare feit heeft gepleegd omdat de normen van zijn eigen culturele achtergrond hem daartoe 'dwong', hoewel hij op de hoogte was van de strafwaardigheid van zijn gedraging. De beklaagde voert daarbij aan dat hij gehandeld heeft 'onder psychische druk' waardoor zijn schuld is weggenomen. 'Niet-vrije-wil-verweer' wordt zelden aangenomen op het gebied van levensdelicten, waar in werkelijkheid gestrengheid is vereist. Cognitieve culturele verweren leveren minder problemen op omdat daar meestal geen sprake is van gewelddadig gedrag en de beklaagde na eenmaal verontschuldigd te zijn geweest, in het vervolg op de hoogte is van de geldende norm en die niet meer zal overtreden.

Het verweer kan de strafbaarheid van het feit betreffen. De verdediging kan bijvoorbeeld een cultureel verweer voeren om het voor het openbaar ministerie lastig te maken het bewijs van de juiste omstandigheden van de zaak te leveren en tot een volledige bewezenverklaring te komen of om de gekozen delictsomschrijving te betwisten. Culturele achtergronden worden ook vaak aangevoerd op het niveau van de strafuitsluitingsgronden. Het betreft in de eerste plaats het verweer van noodweer. De meest gebruikelijke strafuitsluitingsgrond is evenwel psychische overmacht. Een tussenvorm is de dissociatie of tijdelijke ontoerekenbaarheid. Ook kan men een ziekelijke stoornis of gebrekkige ontwikkeling van de geestesvermogens aanvieren, maar dat kan men in elke strafzaak doen.

Het culturele verweer kan ten slotte bestaan in een beroep op een gewetensbezwaar of als persoonlijke omstandigheid. De kans op slagen van een beroep op dat verweer is erg klein. Voor de meeste bekende gewetensbezwaren is het beroep op het gewetensbezwaar wettelijk geregeld en in de andere gevallen die vaak een gewelddadig karakter hebben, zal het niet worden aanvaard. Culturele achtergronden kunnen tenslotte worden aangevoerd bij de straftoemeting.

I48. S. d'Hondt, m.m.v. K. Beyens, B. Machiels, M. Meeuwis, J. Blommaert en J. Verschueren, Interculturele communicatie in rechtbanken, Brussel, Politeia, I994.

I49. M. Bockstaele, 'Tolken in het politieverhoor', Custodes 2000, afl. I, 85-100. 


\subsection{Cultureel verweer in België}

Anders dan in de VSA waar A.D. Renteln moet pleiten voor de invoering van een formeel cultuur verweer, bestaat er in België geen principiële beperking om de strafrechter te vragen de culturele achtergrond in aanmerking te nemen bij zijn vonnis. In het volgende hoofdstuk zullen, op de voorzet van M. Siesling, enkele mogelijke culturele verweermiddelen onder de loep worden genomen.

\section{$6 \quad$ Culturele achtergrond en strafvonnis}

Hierna worden enkele gevallen van verwijzing naar de culturele achtergrond in het strafvonnis - namelijk deze waarvan er sporen zijn te vinden in de Belgische rechtspraak - in snelle ogenschouw genomen: de onbekendheid met de wet; de dwang van de cultuur bij schennis van de seksuele eer en bij laster, eerroof en belediging, de culturele duiding van de uitvoering van het misdrijf, en ten slotte de straftoemeting bij een cultureel misdrijf.

\section{I Onbekendheid met de wet}

In België huldigt men een viertal theoretische zienswijzen betreffende de onderscheiden bestaansvoorwaarden van een misdrijf..$^{150}$ Welke ook de juiste moge zijn, iedereen gaat ermee akkoord dat elk misdrijf een materieel en een moreel element vereist. ${ }^{15 \mathrm{I}}$ Dit vereiste van een moreel element, dit is een bepaalde schuldvorm, is inderdaad een algemeen rechtsbeginsel. ${ }^{152}$

De mogelijke strafrechtelijke schuldvormen zijn opzet en onachtzaamheid. Opzet veronderstelt dat de dader de strafbaar gestelde handeling of onthouding heeft gewild, terwijl hij zich bewust was van het wederrechtelijke karakter ervan, ongeacht de gevolgen. Opzet omvat dus twee elementen. Enerzijds moet de dader geweten hebben dat zijn gedraging een inbreuk vormde. Anderzijds moet hij de bedoeling hebben gehad het materiële bestanddeel van het misdrijf te verwezenlijken; hij moet het verbodene hebben gewild. Het opzet mag niet verward worden met de drijfveer van de dader. Het motief heeft niets te maken met de strafrechtelijke opzet. ${ }^{\text {I53 }}$

Wat de wetenschap van het strafbare karakter van de gedraging betreft, geldt in strafzaken het maxime: 'nemo censetur ignorare legem' of 'niemand wordt geacht de wet niet te kennen'. 54 Hiermee wordt bedoeld dat niemand zich kan beroepen op zijn onwe-

I50. Voor een samenvatting zie F. Tulkens, M. van de Kerchove, Introduction au droit pénal, Wolters Kluwer Belgium, Waterloo, 2007, 334-337.

I5I. Bijv. Cass. P.05.037I.N, 27 september 2005, www.cass.be; Pas. 2005, I75I; TFRnet http://tfrnet.larcier.be; T. Strafr. 2006, 83, noot.

152. Kuty, F., Principes généraux du droit pénal belge. 1. La loi pénale, Larcier, Bruxelles, 2007, nr. 784.

I53. Zie in dit verband L. Dupont \& R. Verstraeten, Handboek Belgisch Strafrecht, Acco, Leuven-Amersfoort, I990, 248 e.v.; C. van den Wyngaert, Strafrecht, strafprocesrecht \& internationaal strafrecht, Maklu, Antwerpen-Apeldoorn, 2006, 276-278.

I54. C. de Koninck, Latijnse rechtsspreuken, Mys \& Breesch, Gent, I998, III. 
tendheid om vrij uit te gaan. ${ }^{155}$ Men kan dan ook in beginsel zijn onwetendheid van het bestaan van de wet en van haar inhoud niet inroepen, wanneer de wet op regelmatige wijze werd bekendgemaakt.

Reeds in de $19^{e}$ eeuw aanvaardde men uitzonderlijk onwetendheid als schulduitsluitingsgrond, wanneer ze betrekking heeft op het bestaan van een wet die een feit strafbaar stelt welke dat voorheen niet was. Als dergelijke onwetendheid onoverwinnelijk was, bijvoorbeeld omdat de beklaagde zwaar ziek was, in het buitenland verbleef of omwille van enige andere reden in de absolute onmogelijkheid verkeerde van de nieuwe wet kennis te nemen, dan ontbreekt het morele element van het misdrijf. ${ }^{156}$

De veronderstelling die men in de $\mathrm{I}^{\mathrm{e}}$ eeuw maakte betrof een burger die terug was van tijdelijk weggeweest. Men kan ze evenwel doortrekken naar de vreemdeling die maar pas in het rijk is aangekomen. De belangrijkste strafbaarstellingen van het strafwetboek behoren ongetwijfeld tot het normale verwachtingspatroon van elke redelijke mens, welke ook zijn culturele achtergrond is. Hij zal er zich ook aan mogen verwachten dat hier te lande bepaalde activiteiten aan reglementaire voorschriften onderworpen zijn. Goede trouw is weliswaar op zich geen rechtvaardigingsgrond, ${ }^{157}$ maar dit neemt niet weg dat het uitzonderlijk kan voorkomen dat een redelijke en voorzichtige vreemdeling die zich pas op het grondgebied bevindt, onwetend is van een van de talrijke wettelijke verplichtingen van meer reglementaire aard waarvan hij redelijkerwijs het bestaan niet kon vermoeden. ${ }^{158}$ Het lijkt niet onredelijk te veronderstellen dat de strafrechter in dergelijk geval een beklaagde zou vrijspreken.

\subsection{Dwang van de cultuur}

\subsubsection{Schennis van de seksuele eer}

In nummer 5.2. werd aangegeven dat de eer onder meer begrepen wordt in de zin van eerbaarheid en kuisheid in het seksuele gedrag en dat aantasting ervan kan leiden tot eerwraak. In die betekenis heeft de eer te maken met wat in ons recht 'goede zeden' wordt genoemd en is ze van oudsher een rechtsgoed, dat strafrechtelijk wordt beschermd. ${ }^{159}$ Met goede zeden doelt men inderdaad op de seksualiteitsbeleving. Verscheidene strafbaarstellingen betreffende de aanranding van de eerbaarheid, verkrachting, ontucht, prostitutie, seksreclame, en zedenschennis beogen de

I55. Cass. 8568, 26 maart I985, Arr. Cass. I984-85, I024; Bull. I985, 938; Pas. I985, I, 938.

I56. J.J. Haus, Principes généraux du droit pénal belge, I, Gent, Librairie générale Ad. Hoste, I879, nr. 704 e.v.; zie ook Cass. 6 oktober 1952, Pas. 1953, I, 37.

157. Cass. 22 oktober 1956, Pas. I957, I, I68.

I58. Vgl. met rechtsdwaling:

- Cass. P.oI.1006.N, I oktober 2002, www.cass.be; T. Gez. 2004-05, I3I, noot T. Balthazar, 'Het gedeeld beroepsgeheim is geen uitgesmeerd beroepsgeheim'.

- Cass. P.oI.I202.F, 29 mei 2002, www.cass.be; Arr. Cass. 2002, I375; Pas. 2002, 1236.

- Cass. P.or.Ioo6.N, I oktober 2002, www.cass.be; Arr. Cass. 2002, 2008; Pas. 2002, I787; RABG 2003, 798, noot L. Delbrouck, '[Onoverwinnelijke dwaling] Ook een advocaat kan zich vergissen'.

159. L. Stevens, Strafrecht en seksualiteit. De misdrijven inzake aanranding van de eerbaarheid, verkrachting, ontucht, prostitutie, seksreclame, zedenschennis en overspel, Intersentia, Antwerpen-Groningen, 2002, nr. 5I4 e.v. 
toename of de verspreiding van bepaalde vormen van de menselijke seksualiteitsbeleving of voorstellingen tegen te gaan. De toetsteen daarbij is de meerderheidsvisie betreffende de menselijke seksualiteitsbeleving.

Op huidig ogenblik wordt deze door de meerderheid opgevat als een intermenselijke, exclusieve, zich in verborgenheid en buiten een familiale context afspelende activiteit tussen twee personen die een minimale leeftijd bereikt hebben, en waarin geen plaats is voor geweld, pijn of vernederingen. Niet elk gedrag dat van de meerderheidsvisie afwijkt, wordt echter strafwaardig geacht. De wet poogt wel met verscheidene strafbaarstellingen de toename of verspreiding van bepaalde vormen van de menselijke seksualiteitsbeleving of voorstellingen ervan tegen te gaan. $\mathrm{Zij}$ besteedt daarbij bijzondere aandacht aan de bescherming van de minderjarige en van de openbare - in de ruimtelijke zin van het woord - moraliteit; zij biedt ook bescherming van de seksuele integriteit tegen een ingrijpen zonder een geldige toestemming, maar waarborgt tevens de 'privacy' van de burger en zijn seksueel zelfbeschikkingsrecht.

Wie in een Belgische juridische databank zoekt naar 'eerwraak', zal nagenoeg niets vinden. Zoveel is nochtans duidelijk dat het niet aan leden van bepaalde groepen van de samenleving staat een lid van de groep recht op seksueel zelfbeschikkingsrecht te ontzeggen en zeker niet hun al dan niet van de meerderheidsvisie afwijkende opvattingen betreffende de menselijke seksualiteitsbeleving of voorstellingen ervan te handhaven door zelf straf op te leggen en te voltrekken. Het strafrecht duldt geen eerwraak en vergoelijkt ze nooit.

Dat er weinig juridische sporen van eerwraak zijn, belet niet dat ze voorkomt. Volksvertegenwoordiger mevr. M. Taelman stelde midden 2006 de minister van Justitie een vraag betreffende 'misdrijuen in het kader van de erewraak'. ${ }^{\text {16o }}$ De minister van Justitie, mevr. L. Onkelinx, antwoordde:

'Er bestaat in België geen exact cijfermateriaal over het aantal dossiers in verband met eer- of bloedwraak. Er is immers geen specifieke preventiecode beschikbaar op basis waarvan dergelijke dossiers in de databanken van de parketten worden ingebracht. Het is evenwel zo dat er gevallen van misdrijven in het kader van eerwraak zijn in België. Meestal betreft het dossiers waarbij personen van Turkse of Marokkaanse oorsprong betrokken zijn.

Volgens informatie die mij met betrekking tot dit onderwerp door de Federale Politie werd overgemaakt, blijkt dat er in ons land een paar eremoorden zijn gepleegd in de voorbije zes jaar. In de Algemene Nationale Gegevensbank van de politiediensten is "geschonden eer" echter niet opgenomen als parameter. Het aantal feiten dat in deze context werd gepleegd is daardoor niet gekend. ${ }^{\mathrm{I} 6 \mathrm{I}}$

I6o. Vraag nr. I049 van 7 juni 2006: www.dekamer.be/QRVA/pdf/5I/5IKor29.pdf.

I6I. Antwoord van 20 december 2006: www.dekamer.be/QRVA/pdf/5I/5IKor48.pdf. 
Bij de senaat werd in 2008 nog een Voorstel ontwerp van resolutie ter bestrijding van de vermeende eerwraak in België ingediend. ${ }^{162}$ Het stelt een aantal juridische en andere maatregelen voor:

'I. Statistische gegevens te verzamelen over de frequentie van die misdaden, met een uitsplitsing per leeftijd, meer bepaald door de tenlasteleggingscodes die in de processen-verbaal worden gebruikt bij het indienen van een klacht, nog meer te specificeren;

2. De Belgische wet van 25 april 2007 die de strafbaarstelling en het uitbreiden van de middelen tot nietigverklaring van het gedwongen huwelijk beoogt, uit te voeren;

3. Toe te zien op de effectieve toepassing van de nieuwe bepalingen van de wet van I5 december 1980 over de toegang tot het grondgebied, het verblijf, de vestiging en de verwijdering (artikel 48/3) zoals gewijzigd door de wet van 15 september 2006 die onder meer bepaalt dat de vluchtelingenstatus kan worden toegekend aan personen die vervolgd worden of vervolgd kunnen worden 'om genderspecifieke redenen' die meer bepaald gericht kunnen zijn op de vermeende eerwraak zoals uiteengezet in de memorie van toelichting;

4. Ervoor te zorgen dat er systematisch een proces-verbaal wordt opgesteld van de klachten over geweld of mishandeling in verband met de vermeende eer van de familie en dat dit aan het parket wordt bezorgd;

5. Erop toe te zien dat die misdaden efficiënt onderzocht en vervolgd worden. ${ }^{\mathrm{I} 63}$

\subsubsection{Laster, eerroof en belediging}

Zoals ook al in nummer 5.2. werd vermeld, kan eer ook begrepen worden in de zin van aanzien, prestige en waardigheid. Ook bij ons zijn 'eer' en 'goede naam' traditionele rechtsgoederen. Aantasting daarvan is strafbaar gesteld als laster, eerroof en belediging. ${ }^{\text {I64 }}$ Ter herinnering: laster en eerroof (art. 443 en 444 Sw.) is iemand, in wettelijk bepaalde omstandigheden van openbaarheid, een bepaald niet-bewezen feit ten laste te leggen dat van aard is zijn eer te krenken of hem aan de openbare verachting bloot te stellen. Het onderscheid tussen laster en eerroof ligt hierin dat bij laster de wet toelaat het bewijs van het bepaalde feit te leveren en bij eerroof niet. Belediging (art. $448 \mathrm{Sw}$.) bestaat erin iemand, in de wettelijke bepaalde omstandigheden van openbaarheid, tot of over iemand een kwaadwillige aantijging uit te spreken zonder een bepaald feit ten laste ten leggen. De laster, eerroof of beledigingen tegen bijzondere personen gepleegd, bedoeld wordt privépersonen, kunnen niet worden vervolgd dan op klacht van de persoon die beweert beledigd te zijn (art. $450 \mathrm{Sw}$.).

Het is niet moeilijk te begrijpen wat laster kan zijn, want hij berust op wettelijk bewijsbare onwaarheid; hij kan slechts strafbare feiten betreffen die uit een vonnis kunnen blijken of feiten die door een authentieke akte kunnen worden vastgesteld. ${ }^{{ }^{6} 5}$

I62. S.4-678 'Voorstel van resolutie ter bestrijding van de vermeende eerwraak in België': 8 april 2008: www.senate. be/www/?MIval=dossier\&LEG=4\&NR=678\&LANG=nl.

I63. zie ook Dienst voor Strafrechtelijk beleid: 'Geweld in de privésfeer': www.dsb-spc.be/web/ index.php?option=com_content\&task=view\&id=58\&Itemi...

I64. A. de Nauw, Inleiding tot het bijzonder strafrecht, gecit., 215-229.

I65. J. Leclercq, in Les Novelles, Droit pénal, IV, Larcier, Bruxelles, I989, nr. 7202-17203. 
De eer is daarentegen het gevoelen dat ze hebben omtrent hun moraliteit, eerlijkheid of rechtschapenheid; de goede naam duidt op iemands aanzien bij derden. ${ }^{\mathrm{I} 66}$ Het zal niet steeds gemakkelijk uit te maken vallen welke aantijgingen nu al dan niet terecht als eerroof of belediging in de zin van de art. 443, 444 en 448 Sw. konden worden ervaren, daar eergevoelen erg persoonlijk en vaak cultuurgebonden is.

\subsubsection{Grond van rechtvaardiging}

Een rechtvaardigingsgrond is een door de wet of rechtspraak bepaalde omstandigheid die in de regel in het algemeen een strafbare gestelde gedraging haar wederrechtelijkheid ontneemt en hierdoor de strafbaarheid ervan opheft. Een rechtvaardigingsgrond betreft het feit: is hij voorhanden dan gaan alle deelnemers aan misdrijf vrij uit. ${ }^{167}$ Wettige verdediging of noodweer - gemeenlijk: 'zelfuerdediging' - is zo een grond van rechtvaardiging. Volgens art. $4 \mathrm{I} 6$ Sw. zijn inderdaad gerechtvaardigd de doodslag, verwondingen en slagen die geboden zijn door de ogenblikkelijke noodzaak van de wettige verdediging van zichzelf of van een ander persoon. Met deze rechtvaardigingsgrond worden nog twee bijzondere gevallen gelijkgesteld (afweer bij nacht van inklimming of braak in een bewoond huis of appartement en verweer tegen plundering of diefstal met geweld tegen personen) die hier - behoudens vergissing - niet in beeld kunnen komen (art. 4I7 Sw.).

Anders dan in de meeste andere landen is noodweer naar Belgisch recht een bijzondere rechtvaardigingsgrond en geen algemene. ${ }^{168}$ De toepassingsvoorwaarden van de wettige verdediging zijn: enerzijds moet de aanval ernstig zijn; effectief zijn begonnen, of minstens dreigen zijn; onrechtmatig zijn en gericht tegen personen; anderzijds moet de verdediging noodzakelijk zijn, in verhouding staan tot de aanval; plaatshebben vóór of tijdens de aanval, niet daarna. De omstandigheid dat wettige verdediging in beginsel een bijzondere rechtvaardigingsgrond is, doet er niet aan af dat zij niet beperkt wordt tot slagen en verwondingen. Minder ernstige vormen van verweer worden vanzelfsprekend ook gerechtvaardigd.

Momenteel is er vooral discussie over de wettige verdediging vanwege de benadeelden van ramkraken. ${ }^{169}$ Dit terzijde gelaten, wettige verdediging vereist niet noodzakelijk levensgevaar. Ook minder ernstige aanvallen vallen er onder. Zo mag men zich verzetten tegen een aantasting van de eerbaarheid of een verkrachting. Wel mag bij een handtastelijkheid die de eerbaarheid krenkt, maar de beheersing van de wil niet wegnam, geen gebruik worden gemaakt van een afweertechniek die niet in verhouding is met het geweld van de aanval. Zo mag hij die zich met geweld verzet tegen een aanranding van de eerbaarheid, geen gebruik maken van een afweertech-

I66. J. Doucet, La protection pénale de la personne humaine, Faculté de Droit, d'Economie et de Sciences Sociales de l'Université de Liège, I979, $201-206$.

I67. L. Dupont \& R. Verstraeten, Handboek Belgisch Strafrecht, gecit., I990, 2I2 e.v.; C. van den Wyngaert, Strafrecht, Strafprocesrecht \& internationaal strafrecht, gecit., I98; F. Tulkens \& M. van de Kerchove, Introduction au droit pénal, gecit., 338 e.v.

I68. T. Ongena, 'Wettige verdediging of noodweer', bijgewerkt tot I mei 2000, in Commentaar Strafrecht en strafuordering, Kluwer Mechelen, in het bijzonder nr. 5 .

I69. P. de Hert, P. van der Meij, 'Op weg naar de Far West? Wettige zelfverdediging naderbij bekeken', Vigiles (N) 2004, 33-39. 
niek - een judoslag die op het hoofd met blokkering van de voet waardoor de aanvaller in de revier gleed en tenslotte verdronk - die niet in verhouding is met het geweld van de aanval. ${ }^{170}$ Het is inderdaad de feitenrechter die onaantastbaar oordeelt over de ernst en de actualiteit van de onrechtmatige aanranding alsook over de noodzaak en de evenredigheid van het verweer, op grond van de feitelijke omstandigheden en rekening houdende met de reacties die de aangerande persoon redelijk kon of moest hebben. ${ }^{\text {I7I }}$

Of noodweer kan worden aangenomen bij aantasting van de eer is omstreden. Toch kan het eventueel op voorwaarde dat de aanval ernstig is. ${ }^{172}$ Een vrederechter oordeelde dat uit het geseponeerde strafdossier weel bleek dat het slachtoffer de dader van de vuistslag meermaals beledigd had, maar dat het niet aangetoond was dat de beledigingen ernstig moreel geweld uitmaken waarvan de dader in die mate onder de indruk kon zijn dat hij zich bedreigd zou moeten voelen, dat zijn veiligheid in het gedrang zou komen, of dat zich van hem een verontwaardiging meester zou moeten maken die heviger en dieper is dan die welke voortvloeit uit lichamelijk geweld. De beledigde dader is dan ook volledig civielrechtelijk aansprakelijk voor de gevolgen van de slag. ${ }^{173}$

\subsubsection{Grond van verschoning}

Een verschoningsgrond is een door de wet bepaalde feitelijke omstandigheid die bij de dader of medeplichtige van bepaalde misdrijven de persoonlijke verwijtbaarheid van de wederrechtelijk blijvende gedraging wegneemt of vermindert en aldus leidt tot persoonlijke straffeloosheid of wettelijke strafmatiging. ${ }^{174}$ De verschoningsgrond die bij een cultureel misdrijf vooral aan bod zal komen, is deze van art. 4II Sw. Dit artikel bepaalt dat doodslag, verwondingen of slagen verschoonbaar zijn, indien zij onmiddellijk uitgelokt worden door zware gewelddaden tegen personen. ${ }^{175}$ Onder de vermelde misdrijven valt ook moord. ${ }^{\mathrm{I7} 6}$ Art. $4 \mathrm{I} 4$ Sw. regelt de strafvermindering.

De wet geeft geen definitie van provocatie of uitlokking. Het is, zegt men, het feit dat bij iemand woede of vrees opwekt die hem ertoe bracht een misdrijf te plegen als reactie daartegen. Provocatie tast de vrijheid van geest en wil aan. Het is een persoonlijke omstandigheid van de geprovoceerde. De uitlokking moet zwaar zijn en de reactie ertegen moet onmiddellijk zijn gevolgd of minstens plaats hebben gegrepen zolang de hevige emotie die eruit volgde, duurde. ${ }^{177}$ Wat de zware gewelddaden tegen personen betreft, dit gaat in principe uitsluitend om fysieke geweld-

I70. Antwerpen 27 mei I98I, Pas. I982, II, 3; R.W. I983-84, I899, noot P. Arnou, 'Wettige verdediging bij aanranding van de eerbaarheid'.

I7I. Cass. P.02.0358.F, I2 juni 2002, Arr. Cass. 2002, I490; www.cass.be; Pas. 2002, I34I.

I72. P.-E. Trousse, Droit Pénal, Tome I Vol. I, in Les Novelles, Bruxelles, Larcier, I956, nr. 265 I.

I73. Vred. Doornik (2) nr. 02A784, 8 april 2003, T. Verz. 2004, I84.

174. L. Dupont \& R. Verstraeten, Handboek Belgisch Strafrecht, gecit., 288 e.v.; C. van den Wyngaert, Strafrecht, Strafprocesrecht \& internationaal strafrecht, gecit., 238 e.v.

I75. R.P.D.B., compl. VIII, Bruylant, Bruxelles, I995, tw., 'Coups et blessures', nr. 3I9-374.

I76. Luik 20 juli i979, J.T. ı979, 6ro.

I77. K.I. Bergen I2 augustus I988, Rev. dr. pén. I989, IIo, noot J.S. 
daden. Beledigingen of niet-onmiddellijke bedreigingen maken geen grond tot strafvermindering uit. Dit kunnen daarentegen wel verzachtende omstandigheden zijn. Tenslotte is de provocatie een louter objectieve omstandigheid.

Sedert een eeuw reeds wordt aangenomen dat ook ernstige geestelijke gewelddaden uitlokking kunnen uitmaken. ${ }^{178}$ Ook in de recentere rechtsprak vindt men daarvan voorbeelden. Zo oordeelde een correctionele rechtbank dat de uitlokking het gevolg kan zijn van geestelijke gewelddaden, voor zover het gaat om zware gewelddaden waarvan iedere redelijke mens zo sterk onder de indruk kan komen dat hij zich bedreigd voelt, dat zijn veiligheid in het gevaar komt of dat er in zijn hoofde een sterkere en diepere verontwaardiging rijst dan die als gevolg van lichamelijke gewelddaden. ${ }^{179}$ Overigens kan een uitlokking dermate gewelddadig zijn, dat zij een vrijspraak wegens noodweer rechtvaardigt. ${ }^{\text {I80 }}$

Een discussiepunt in de rechtsleer was of provocatie uitsluitend beoordeeld moet worden aan de hand van objectieve criteria dan wel of ook met subjectieve criteria rekening mag worden gehouden. Die laatste zienswijze blijkt het te hebben gehaald. Rechters houden rekening met de persoon van de geprovoceerde, diens opvoeding, gewoonte en vooroordelen. ${ }^{\mathrm{I} I \mathrm{I}} \mathrm{Bij}$ de eerroof bijvoorbeeld is het subjectief element belangrijk. Een hof van beroep oordeelde dat wanneer de woorden van het slachtoffer, zelfs subjectief gezien, de eer of de goede naam van de beklaagde geenszins in het gedrang hebben gebracht, en het slachtoffer geen enkele daad heeft gesteld die een hevige emotie kon uitlokken, de beklaagde geen uitlokking als verschoningsgrond kan inroepen. ${ }^{182}$ Dit wil met andere woorden zeggen dat het hof de aantasting van de eer en de goede naam, subjectief gezien, eventueel wel in afweging zou hebben genomen.

\subsection{Duiding van de uitvoering van het misdrijf}

De vreemde culturele achtergrond kan een stuk van de uitlegging en duiding verstrekken van de uitvoering van en de deelneming aan een misdrijf. Hij maakt de omstandigheden van het gebeurde, de motieven en het aandeel van de verschillende deelnemers - en eventueel van het slachtoffer - begrijpelijk. De vreemde culturele achtergrond laat toe de strafrechtelijke verantwoordelijkheid en de respectieve graad schuld van daders, mededaders en medeplichtigen te wegen bij misdrijven waarbij een ganse maatschappelijke groep betrokken zoals dat bijvoorbeeld bij eerwraak het geval kan zijn.

Zonder twijfel houdt de Belgische strafrechter rekening met de vreemde culturele achtergrond indien die een rol heeft gespeeld. Nochtans vindt men in de overwegingen van de gepubliceerde rechtspraak maar zelden verwijzingen naar de culturele achtergrond van de zaak. Het gaat dan nog om vonnissen van anderen dan strafrech-

I78. R.P.D.B., compl. VIII, gecit., tw. 'Coups et blessures', nr. 344 en de daar geciteerde rechtsleer.

I79. Corr. Aarlen 8 februari I990, J.L.M.B. I991, II85.

I80. Corr. Tongeren 20 juni I990, R.W. I990-9I, 545, noot B. Spriet, 'Noodweer of wettige verdediging als rechtvaardigingsgrond in het strafrecht'.

I8I. Luik, I5 januari I986, Jur. Liège, I986, 243; K.I. Bergen, I2 augustus ı988, Rev. dr. pén. I898, I6.

I82. Bergen 3 juni 1992 , Rev. dr. pén. I993, 465. 
ters. Zo verwees een arbeidsrechtbank onder meer naar de culturele achtergrond van de werknemer om te oordelen dat een door hem gepleegde diefstal, niet als een dringende reden tot ontslag kan worden beschouwd. ${ }^{183}$ Een kort gedingrechter die moest beslissen over de toewijzing van het bestuur van de persoon en de goederen van een kind aan één van de twee ouders, achtte het nodig om met behulp van een 'pedopsychiatrisch' team na te gaan in welk ouderlijk milieu de belangen van het kind het best worden beschermd en welke ouder het daadwerkelijk zal toelaten diepgaande contacten te bewaren met de andere en open te staan voor de zoektocht naar de dubbele culturele achtergrond. ${ }^{\mathrm{I} 84}$ Een andere voorzitter nam de culturele achtergrond mede in aanmerking om de bedoeling van partijen een duurzame levensgemeenschap te vormen, te beoordelen. ${ }^{185}$ De Vaste Beroepscommissie Vluchtelingen oordeelde dat de motivering van een bestreden beslissing het niet mogelijk maakte te begrijpen waarom de leeftijd van een verzoeker op het ogenblik dat hij wees werd, zijn heel lage opvoedingsgraad, alsook de culturele context waarin hij leefde geen voldoende uitleg vormen voor zijn betrekkelijke onwetendheid betreffende de volledige naam van zijn vader en moeder, die beiden overleden waren toen hij nog kind was. ${ }^{\text {I }}{ }^{86}$

De vraagt die rijst is of de culturele achtergrond elke schuld bij een van de deelnemers van een groepsmisdrijf kan uitsluiten. Het handelen van een bepaald individu kan inderdaad in een bepaalde culturele achtergrond dermate ondergeschikt en automatisch zijn geweest, dat hij blijkbaar geen eigen bewustzijn en vrije wil had. Kan dit elke schuld wegnemen? Deze vraag zal een Nederlandse penalist waarschijnlijk niet verrassen, een Belgische misschien des te meer. Toch zijn er aanwijzingen dat dit ook in het Belgisch strafrecht mogelijk moet zijn. Inzake valsheid in geschrifte ontwikkelde men de idee van de 'middellijke dader', d.i. de dader die zelf niet handelt maar een ander als instrument gebruikt. ${ }^{\text {I87 }}$ Iemand die een derde als instrument heeft gebruikt om een valsheid in geschrifte te plegen, wordt zelf als de rechtstreekse dader van het misdrijf beschouwd. ${ }^{\text {I8 }}$ Men nam dit ook aan voor beklaagde die door misleiding iemand die zelf te goeder trouw was, ertoe gebracht had bij de verzekeringsmaatschappij een valse ongevalsaangifte te doen. ${ }^{189}$ Niets lijkt dan ook in de weg te staan dat, toegegeven in uitzonderlijke omstandigheden, aan te nemen is dat iemands culturele achtergrond hem louter willoos instrument in andermans handen heeft gemaakt.

I83. Arbrb. Nijvel 7 mei I99I, R.S.R. I99I, 344.

I84. Kort Ged. Rb. Brussel I3 januari I995, Rev. trim. dr. fam. 1996, 400.

I85. Kort Ged. Rb. Antwerpen nr. 05/3039/A, 29 september 2005, T. Vreemd. 2005 (verkort), 4Io.

I86. Vaste Beroepscommissie Vluchtelingen nr. 05-I200, 6 maart 2007, Rev. dr. étr. 2007, I42, 40; T. Vreemd. 2007 (verkort), 205.

I87. S. van Dyck, Valsheid in geschriften en gebruik van valse geschriften, Intersentia, Antwerpen, 2007, nr. 386.

I88. Cass. 8335, 6 maart I984, Arr. Cass. I983-84, 851; Bull. I984, 782; Pas. I984, I, 782.

I89. Cass. 606o, 9 maart I993, www.cass.be; Arr. Cass. I993, 268; Bull. I993, 260; Pas. I993, I, 260. 


\subsection{Straftoemeting en cultureel misdrijf}

\subsubsection{Cultureel element als wettelijk verzwarende omstandigheid}

In de gewone omgangstaal is de drijfveer, beweegreden of motief, de overweging die de dader tot een bepaalde handeling leidt. Mensen die andermans daad beoordelen, hechten normaal veel belang aan diens drijfveren. In het strafrecht daarentegen is de drijfveer in de regel van geen tel voor het bestaan van het misdrijf. ${ }^{190}$ Zelfs bij misdrijven die een bepaald opzet vereisen, is wettelijk de drijfveer onverschillig. Dit is bijvoorbeeld het geval bij valsheid in geschrifte ${ }^{191}$ omkoping, ${ }^{192}$ onttrekking van minderjarigen, ${ }^{193}$ opzettelijke slagen of verwondingen, ${ }^{\text {I94 }}$ grafschennis, ${ }^{\text {I95 }}{ }^{95}$ bij het 'taartenwerpen'. ${ }^{196}$ Meer nog: de drijfveer voor het misdrijf kan geheel of gedeeltelijk onbekend blijven. ${ }^{\text {I97 }}$

Slechts onlangs is men bij de wettelijke strafbepaling stelselmatig rekening gaan houden met een bepaalde drijfveer. De wet van 25 februari 2003 ter bestrijding van discriminatie en tot wijziging van de wet van I5 februari 1993 tot oprichting van een Centrum voor gelijkheid van kansen en voor racismebestrijding, heeft namelijk in het Strafwetboek bepalingen ingevoegd die ondermeer strafverzwaring mogelijk maken voor bepaalde misdrijven wanneer een van de drijfveren bestond in de haat tegen, het misprijzen van of van de vijandigheid tegen een persoon wegens diens zogenaamd ras, zijn huidskleur, zijn nationale of etnische afstamming, zijn geslacht, zijn seksuele geaardheid, zijn burgerlijke stand, zijn geboorte, zijn vermogen, zijn geloof of levensbeschouwing, een handicap of een fysieke eigenschap.

Die wettelijke mogelijkheid tot zwaardere bestraffing betreft:

- aanranding van de eerbaarheid en verkrachting (art. 377bis Sw.);

- $\quad$ opzettelijke slagen of verwondingen en verschillende soorten van doodslag (art. 405quater Sw.);

- $\quad$ schuldig verzuim hulp te verlenen aan een persoon die in groot gevaar verkeert of weigering of nalaten de hulpverlening te bieden waartoe men wettelijk opgevorderd werd (art. 422quater Sw.);

- $\quad$ aanslag op de persoonlijke vrijheid en op de onschendbaarheid van de woning door bijzondere personen (art. 438 bis Sw.);

I9o. Cass. 6976, 5 oktober I988, Arr. Cass. I988-89, I42; Bull. I989, I27; J.L.M.B. I989, 286; Pas. I989, I, I27; Rev. dr. pén. 1989,99 , noot J.S.

I9I. Cass. P.94.55I.F, 26 oktober I994, www.cass.be; Arr. Cass. I994 (samenvatting), 878; Bull. I994 (samenvatting), 860; Pas. I994 (samenvatting), I, 860.

192. Cass. (verenigde kamers) A.94.000I.F, 23 december 1998), www.cass.be; A.J.T. I998-99, 54I; Arr. Cass. 1998, Ir66; Bull. 1998, I256; J.L.M.B. I999, 6r en http://jlmbi.larcier.be; R.W. 1998-99, I309 en www.rwe.be; Rev. dr. pén. 1999, 393.

I93. Corr. Kortrijk (8e k.) 28 april I997, TWVR 2000, 8I (dit vonnis betrof het thans opgeheven art. 36 gbis Sw.).

I94. Cass. 56I5, 25 februari I987, Arr. Cass. I986-87, 840; Bull. I987, 76I; Pas. I987, I, 76I; Rev. dr. pén. I987, 692; K.I. Mons I5 juni I999, Rev. dr. pén. 2000, 742.

I95. K.I. Antwerpen 3 juni I999, R.W. 2000-or, I7, en www.rwe.be, noot P. Arnou, 'Grafschennis, het fotograferen van lijken en het betreden van mortuaria en funeraria'.

I96. Paris (Fr.) 4 juni 2003, Journ. proc. 2003, afl. 462, 26, noot J. Buyle, 'L'Entartage de Chevènement: crème et châtiment'.

I97. Mons 8 februari I985, J.T. I985, 593. 
- belaging (art. 442ter Sw.);

- $\quad$ aanranding van de eer en de goede naam, door laster, eerroof of belediging (art. 453 bis Sw.);

- $\quad$ grafschennis (art. 453bis Sw.);

- brandstichting (art. 5I4bis Sw.);

- vernielingen van roerende eigendommen (art. 532bis Sw.). ${ }^{198}$

De wet van 25 februari 2003 vereist niet dat de haat, het misprijzen of de vijandigheid de voornaamste drijfveer voor het plegen van het misdrijf zou zijn geweest. Het moet slechts één van de drijfveren ervan zijn geweest. Nu zijn drijfveren uiteraard innerlijk. Het bewijs daarvan in een concrete zaak, zal dan ook niet steeds eenvoudig zijn. Het zal moeten afgeleid worden uit bepaalde gedragingen of uitlatingen van de dader. ${ }^{199}$ Wat er ook van zij, het ontwarren van de uitwendige aanleiding of oorzaak van een misdrijf, de omstandigheden van feit, de persoonlijke omstandigheden van de dader en ten slotte zijn innerlijke drijfveren, lijkt uitzonderlijk delicaat. Wellicht zullen bij de straftoemeting meerdere van deze elementen tezelfdertijd in beeld komen. ${ }^{200}$ Zo nam een rechter de vele spijtbetuigingen in aanmerking van een beklaagde die racistische en antisemitische opschriften op de bagage van vliegtuigpassagiers had aangebracht, om deze een opschorting van lange duur te verlenen. ${ }^{20 I}$

\subsubsection{Cultureel element als verzachtende omstandigheid}

Volgens de art. 79 tot $85 \mathrm{Sw}$. vermag de rechter voor misdaden of wanbedrijven steeds verzachtende omstandigheden aan te nemen, waardoor de op die misdrijven gestelde straffen wettelijk verminderd of gewijzigd worden. Overeenkomstig art. Ioo Sw. geldt dit ook voor de misdaden, maar niet de wanbedrijven van de bijzondere strafwetten (art. 85 Sw.). ${ }^{202}$ Dat de bijzondere wet niet toelaat bij verzachtende omstandigheden een mildere straf dan de wettelijk bepaalde op te leggen, wordt niet in strijd geacht met art. 6.I EVRM. ${ }^{203}$ Eender hoe, de bijzondere wetten kunnen andersluidend beschikken en bij verzachtende omstandigheden wel strafvermindering of -wijziging toepasselijk maken. ${ }^{204}$

Het Strafwetboek zegt niet welke omstandigheden de rechter als verzachtend moet beschouwen of niet. Hij mag daarvoor elke feitelijke omstandigheid van het gepleegde misdrijf of elke persoonlijke omstandigheid van de dader in aanmerking nemen. Hij is in recht nooit verplicht een bepaalde omstandigheid waarvan hij nochtans het bestaan erkent, als verzachtend te beschouwen of niet. Zelfs een overschrij-

I98. A. de Nauw, Inleiding tot het bijzonder strafrecht, gecit., nr. I67, 244, 270, 296, 300, 32I, 497, 509.

I99. T. Vander Beken, 'Voor de sport. De strafrechtelijke aanpak van discriminatie vanaf 2003', in X., De Wet Bestrijding Discriminatie in de praktijk, Editors: M. de Vos, E. Brems, Intersentia, Antwerpen, 2004, 26I-276, inzonderheid nr. 49-52.

200. Bijv. Corr. Kortrijk nr. 05/230, I6 februari 2005, T. Vreemd. 2005 (verkort), 245, noot I. Aendenboom, 'Strafverzwaring als maatschappelijk wapen'.

20I. Corr. Brussel nr. 002086, I6 maart 2006, Rev. dr. étr. 2006, 50; T. Vreemd. 2006, 420.

202. Cf. Smetryns, 'De motiveringsverplichting van de strafrechter. Een algemene inleiding', CABG 2005, afl. I, 28-30.

203. Cass. P.o6.04I6.N, I2 september 2006, www.cass.be.

204. F. Kuty, Principes généraux du droit pénal Belge, Larcier, Bruxelles, 2007, nr. 307-308. 
ding van de redelijke termijn moet hij niet als verzachtende omstandigheid aannemen. ${ }^{205}$ Kortom het al of niet aannemen van verzachtende omstandigheden behoort tot de discretionaire en een onaantastbare beoordeling van de rechter. Volgens het Hof van Cassatie kan hij ze zelfs voor een bepaalde mede-inverdenkinggestelde, medebeklaagde of medebeschuldigde aannemen, maar niet voor een andere. ${ }^{206}$ Neemt de rechter evenwel aan dat er verzachtende omstandigheden bestaan, dan moet hij de wettelijk daarvoor bepaalde strafvermindering of -wijziging toepassen. ${ }^{207}$

Dat de rechter discretionair en onaantastbaar oordeelt over verzachtende omstandigheden, kan hem niet ontslaan van de verplichting naar redelijkheid te oordelen. Er bestaan inderdaad omstandigheden die algemeen aanvaard worden als verzachtend. Denken we bijvoorbeeld maar aan de geringe belangrijkheid van het feit, de beperkte schuld van de dader, zijn jeugdige leeftijd en de afwezigheid van vroegere veroordelingen, zijn maatschappelijke achtergrond en kansarmoede, beperkte intellectuele talenten en maatschappelijke vaardigheden. Anderzijds moet de rechter het gelijkheids- en non-discriminatiebeginsel in acht nemen, dat vereist dat, behoudens objectieve rechtvaardiging, vergelijkbare situaties niet verschillend en verschillende situaties niet gelijk worden behandeld. ${ }^{208}$ De gerechtigheid verlangt dan ook dat de rechter zijn straftoemeting op een individuele beklaagde zoveel als mogelijk inschrijft in de bestraffing in het algemeen van vergelijkbare misdrijven gepleegd in vergelijkbare omstandigheden gepleegd door vergelijkbare daders. Het excuus dat er niets echt vergelijkbaars bestaat, zou de reinste willekeur zijn.

\subsubsection{Cultureel element als motief voor de straftoemeting}

Ingevolge art. $\mathrm{I}_{3}$, tweede lid, Sv. moet het vonnis van de politierechtbank dat een verval van het recht tot sturen van een voertuig, een luchtschip en het geleiden van een rijdier uitspreekt, nauwkeurig, maar op een wijze die beknopt mag zijn, de keuze en de duur daarvan motiveren. Art. I95, vierde lid, Sv. legt deze bijzondere motiveringsverplichting van het rijverbod ook op aan de correctionele rechtbank die rechtspreekt in hoger beroep. Anderzijds verplicht art. 195, tweede lid, Sv. de correctionele rechtbank die rechtspreekt in eerste aanleg, nauwkeurig, maar op een wijze die beknopt mag zijn, de keuze van een straf of maatregel en de duur ervan te motiveren. Tenslotte eist art. 364 bis Sv., ingevoegd bij Wet van 30 juni 2000, dat het hof van assisen in ieder veroordelend arrest melding maakt van de redenen die geleid hebben tot de bepaling van de straf. ${ }^{209}$

Deze voorschriften bieden zich aan als vormvoorschriften. Dit wil zeggen dat de rechter wel de straftoemeting moet motiveren maar daarbij vrij zijn keuzes maakt.

205. Cass. P.99.I758.F, 22 maart 2000, www.cass.be; Arr. Cass. 2000, 64I; Bull. 2000, 633; J.T. 200I, 46; Rev. dr. pén. 200I, 260.

206. Cass. P.02.1038.F, 2 oktober 2002, www.cass.be; Arr. Cass. 2002, 2043; Pas. 2002, I822.

207. Betreffende misdaden: Cass. P.oo.I7I8.F, I4 maart 200I, www.cass.be; Arr. Cass. 200I, 408; Pas. 200I, 404 .

208. G.W.telijk Hof nr. I28/2007, Io oktober 2007, r.o. 56, www.arbitrage.be, B.S. 24 oktober 2007 (eerste uitgave) (uittreksel), 55108 en http://staatsblad.be.

209. A. Smetryns, 'De motiveringsverplichting van de strafrechter. Een algemene inleiding', gecit., 30-34. 
Hoe zeer men het anders zou wensen, ${ }^{210}$ de keuzes die de rechter maakt, zijn in beginsel onaantastbaar, dit wil zeggen dat het Hof van Cassatie ze niet kan toetsen. De enige controle die theoretisch voor het Hof van Cassatie wordt weggelegd, is deze van de onmenselijke, vernederende of onredelijke straf. Het moge evenwel duidelijk zijn, dat gelukkig daartoe niet snel aanleiding zal zijn.

De rechter kan de straf bepalen naargelang van het abstracte doel van de wettelijke strafbaarstelling of bestraffing, het concrete doel dat hijzelf met zijn straftoemeting beoogt, de gevolgen die de bestraffing zal meebrengen, of hij kan een of meerdere van deze elementen bij zijn beslissing betreffende de keuze van de straf of maatregel en de bepaling van de strafmaat betrekken. ${ }^{2 \mathrm{II}}$ De rechter kan bijvoorbeeld het culturele element van het misdrijf als schadelijk of bedreigend beschouwen of juist niet, of hij kan oordelen dat de dader of derden afgeschrikt moet worden nog een gelijkaardig cultureel misdrijf te plegen of juist niet, of hij kan enig begrip vinden voor de bijzondere omstandigheden van het feit of de bijzondere persoonlijke omstandigheden van dader die hem de redelijke verwachting geven dat deze dergelijk feit niet zal herhalen en de dader en derden zijn mildheid ook niet verkeerd kunnen begrijpen. Soms zal misschien het uitspreken van een principiële afkeuring, reeds voldoende lijken. ${ }^{212}$

Ondanks zijn vrijheid bij de strafbepaling, moet de rechter waken voor zijn werkelijke rechtvaardiging van de strafbepaling en voor de formele motivering die hij daarvoor geeft. Hij mag namelijk de beklaagde nooit straffen voor de wijze waarop deze zich heeft verdedigd. Halsstarrig ontkennen bijvoorbeeld, wat vaak maatschappelijk of cultureel bepaald is, of ten onrechte of vals een cultureel element aanvoeren of het integendeel verdonkeremanen, mogen de beklaagde niet ten kwade worden geduid. ${ }^{213}$ Toch mag, volgens het Hof van Cassatie, de rechter bij de bepaling van de straf rekening houden met de houding die de verdachte tijdens het vooronderzoek aannam tegen de getuigen en de slachtoffers ${ }^{2 \mathrm{I} 4}$ of met de gemoedsgesteldheid en de houding van de beklaagde tegenover de slachtoffers tijdens het onderzoek. ${ }^{215}$ Hiermee gaat de beklaagde kennelijk verder dan zich te verdedigen.

2IO. L. Dupont, 'De motivering van de straftoemeting. Een minicommentaar bij de Wet van 27 april I987 in verband met de motivering van de straffen', In X., Actuele problemen van het strafrecht. XIVde Postuniversitaire Cyclus Willy Delva I987-I988, Interuniversitaire Reeks Criminologie en Strafwetenschappen, nr. I5, Kluwer rechtswetenschappen, Antwerpen - Gouda Quint, Arnhem, I988, 505-530, nr. 35 en 36 .

2II. M. van de Kerchove, 'La motivation des peines et la pluralité de leurs objectifs', Rev. dr. pén. 2006, ro39-1069.

2I2. M. van de Kerchove, 'Quand dire, c'est punir. Essai sur le jugement pénal', Reeks 'Publications des facultés universitaires Saint-Louis', nr. Ior, Facultés universitaires Saint-Louis, Brussel, 2005.

2I3. J. du Jardin, 'Het recht van verdediging in de rechtspraak van het Hof van Cassatie (I990-2003)', R.W. 2003-2004, 76I-790, inzonderheid 780; zie ook J. du Jardin, 'Le droit de défense dans la jurisprudence de la Cour de cassation (I990-2003)', Pas. 2003, I-87, inzonderheid 57-59; voor een verkorte versie, J.T. 2003, 609-625.

214. Cass. P.99.0087.F, I9 mei I999, www.cass.be; Arr. Cass. I999, 692; Bull. I999, 71з; J.T. I999, 645, noot.

215. Cass. P.03.I347.N, 23 maart 2004, www.cass.be; Juristenkrant 2004 (weergave S. Sonck), afl. 88, 6; Pas. 2004, afl. 3, 494; R.W. 2004-05, 790 en www.rwe.be, noot F. Vanneste, 'De vrije keuze van verweer en de motivering van de straf'; T. Strafr. 2005 (verkort), 44. 


\section{$7 \quad$ Vreemde cultuur in het strafproces}

Vooraleer te besluiten, moet nog even gekeken worden naar de vreemde cultuur in het strafproces, zowel vanuit het standpunt van de persoon die voor de strafrechter verschijnt, als vanuit dit van de strafrechter zelf.

\section{I Culturele beleving voor de strafrechter}

\subsubsection{Aanwezigheid als toehoorder}

De rechtszitting wordt geregeld in de art.. 757 tot 763 Ger.W. ${ }^{216}$ Deze wetsbepalingen zijn toepasselijk op de strafgerechten (art. 2 Ger.W.). ${ }^{217}$ Artikel 759 Ger.W. luidt: 'De toehoorders wonen de zittingen bij met ongedekten hoofde, eerbiedig en stilzwijgend; alles wat de rechter tot handhaving van de orde beveelt, wordt stipt en terstond uitgevoerd.' Dit voorschrift geldt voor alle toehoorders, ook getuigen en beklaagden.

Nog na het midden van de $20^{\mathrm{e}}$ eeuw plachten vrouwen van stand een hoed te dragen en tooiden vrouwelijke kloosterlingen zich met een kap of iets dergelijks. Het werd algemeen aanvaard dat zij deze niet moest afnemen in de rechtszittingszaal. Het werd niet beschouwd als een gebrek aan eerbied voor het gerecht. Vandaag dragen vele moslimvrouwen een hoofddoek of hijab. ${ }^{218}$ Moeten zij die afnemen op de rechtszitting? Art. 9.I EVRM waarborgt de vrijheid van gedachte, geweten en godsdienst. Dit recht omvat ondermeer de vrijheid in het openbaar zijn overtuiging te belijden door de praktische toepassing ervan en het onderhouden van de geboden en voorschriften. Hieronder valt ongetwijfeld in beginsel het dragen van een hoofddoek door een moslimvrouw. Volgens art. 9.2 EVRM kan de vrijheid van godsdienst of overtuiging te belijden evenwel aan beperkingen worden onderworpen voor zover die bij de wet zijn bepaald en in een democratische samenleving nodig zijn voor de openbare orde, gezondheid of zedelijkheid of de bescherming van de rechten en vrijheden van anderen. Onder die voorwaarden kon volgens het Europees Hof voor de Rechten van de Mens het verbod van een hoofddoek worden opgelegd aan een onderwijzeres van een openbare school die confessionele neutraliteit en, ruimer gezien, de godsdienstvrede in een multiculturele samenleving beoogt. ${ }^{219}$ Het lijkt er

2I6. L. Verhaegen, 'Art. 757 Ger.W. - Art. 763 Ger.W', bijgewerkt tot 3I januari I983, in Gerechtelijk recht. Artikelsgewijze commentaar met overzicht van rechtspraak en rechtsleer, Kluwer, Mechelen.

217. I.v.m. art. 758 Ger.W. : Cass. I8 september I979, Arr. Cass. I979-80, 63; Pas. I980, I, 60.

218. De hijab is de hoofddoek gedragen door moslimvrouwen. De chador bedekt het ganse lichaam. Bij de boerka is het gehele gezicht bedekt door een soort gaas en zijn de ogen vrijwel niet zichtbaar, terwijl er bij de niqaab een smalle spleet is waardoor de ogen te zien zijn.

2I9. Besl. Hof Mensenrechten (2e afd.) nr. 42393/98, I5 februari 200I (Dahlab/Zwitserland), www.echr.coe.int; AJDA (Fr.) 200I (verkort), 480 en www.ajda.fr, noot J. Flauss, [Le contentieux européen afférent aux limites de la liberté de manifestation des convictions religieuses par le port d'attributs vestimentaires distinctifs]; J. dr. jeun. 2002, afl. 215, 42, noot J. Jacqmain, 'Encore le voile islamique'; Juristenkrant $200 \mathrm{I}$ (weergave E. Brems), afl. 28, I6; R.U.D.H. 200I, 75; Rev. dr. étr. 2003 (samenvatting), afl. 123, 293; Soc. Kron. 2003 (samenvatting), afl. 6, 300, noot J. Jacqmain, 'Encore le voile islamique'; zie ook K. Hanson, 'Art. 9 - Vrijheid van gedachte, geweten en godsdienst, EVRM', in nr. 332, J. Vande Lanotte, Y. Haeck, Handboek EVRM, Deel 2, Volume I, gecit., nr. 33. 
dus op dat het enkel feit dat men als toehoorder met gedekt hoofd voor de rechter verschijnt zonder dat dit kan begrepen worden als een gebrek aan eerbied, moet worden getolereerd. Dit schijnt nochtans niet steeds het geval te zijn.

Onlangs werden Belgen van vreemde origine voor de Correctionele Rechtbank te Antwerpen gedaagd wegens het verzaken van hun opdracht om als bijzitter zitting te nemen in een kiesbureau. Een van de gedaagden was drager van een muts. De rechter verzocht hem dit hoofddeksel af te nemen, wat hij weigerde. De magistraat stelde hem hierop in verdenking voor smaad. Bij de behandeling van die tweede procedure voerde de betrokkene een medische reden aan voor zijn weigering. Omdat in andere gevallen het dragen van een hoofddeksel werd verantwoord door een beroep op de godsdienstvrijheid, vond de rechter het nodig het Grondwettelijk Hof de prejudiciële vraag te stellen:

'Schendt artikel 759 van het Gerechtelijk Wetboek de artikelen ro en II G.W. indien het aldus wordt geïnterpreteerd dat het de toehoorders en beklaagden verboden is de zittingen bij te wonen wanneer zij een hoofddeksel dragen, ook wanneer dit hoofddeksel een uiting is van hun religieuze overtuiging?'

Het G.W.telijk Hof oordeelde evenwel dat de prejudiciële vraag geen antwoord behoefde: de beklaagde had zich voor de verwijzende rechter geenszins beroepen op religieuze redenen, zodat het antwoord op de prejudiciële vraag klaarblijkelijk niet dienstig kan zijn voor de oplossing van het geschil dat voor de verwijzende rechter aanhangig is. ${ }^{220}$ Het arrest van het Grondwettelijk Hof is enigszins verrassend. Het blijkt inderdaad niet dat de correctionele rechter reeds beslist had over het werkelijke of vermeende motief van de dader.

Een andere zaak betrof een draagster van een hijab die samen met andere familieleden als burgerlijke partij verscheen op de rechtszitting van de kamer van inbeschuldigingstelling die moest oordelen over hun hoger beroep tegen de verwijzing naar de correctionele rechtbank van de verdachte van een 'crime passionnel', die haar broer met een kogel in het hoofd had doodgeschoten. De burgerlijke partijen wilden daarentegen dat de verdachte zou terechtstaan voor het hof van assisen. De voorzitster van de kamer van inbeschuldigingstelling vroeg de vrouw haar hoofddoek af te nemen overeenkomstig art. 759 Ger.W. wat zij niet wilde doen. Daarop gaf de voorzitster bevel haar uit de gehoorzaal te zetten. In afwezigheid van de vrouw maar op tegenspraak wat de andere burgerlijke parijen betreft verklaarde de kamer van inbeschuldigingstelling de hogere beroepen ongegrond en bevestigde de verwijzing naar de correctionele rechtbank. De burgerlijke partijen stelden cassatieberoep. Het Hof verwierp het cassatieberoep omdat de wet in dergelijk geval, geen onmiddellijk cassatieberoep toelaat. De vrouw was op de rechtszitting van het Hof opnieuw verschenen met haar hijab. Ze werd deze keer niet uit de gehoorzaal gezet. Of hoe recht niet alleen gesproken wordt met woorden! ${ }^{221}$

220. G.W.telijk Hof, nr. 8/2008 van I7 januari 2008, www.const-court.be.

221. Cass. P.07.1384.F, 25 juni 2008, www.cass.be. 


\subsubsection{Eedaflegging als getuige}

Sedert de oudheid wordt de eed beschouwd als een van de sterkste uitingen van maatschappelijke verbondenheid. ${ }^{222}$ Overeenkomstig art. I92 G.W. kan geen eed worden opgelegd dan krachtens de wet. De wet stelt de verschillende eedformules vast. De eed begint steeds met de woorden: 'Ik zweer'. In de $19{ }^{\mathrm{e}}$ eeuw nog was men van oordeel dat deze woorden op zich een aanroeping van de godheid inhielden. Met de eed neemt men namelijk god als getuige van de oprechtheid van de verbintenis die men aangaat, of van de waarachtigheid van wat men gaat zeggen. ${ }^{223}$ Ofschoon het soms werd betwist, had volgens de vroegere rechtspraak daarom de eed steeds een religieus karakter. Hij werd niet beschouwd als de uiting van een bepaalde godsdienst, maar als de uiting van de monotheïstische levensbeschouwing. Toch aanvaardde men dat de agnosticus de eed naar zijn innerlijke overtuiging als een louter wettelijke verplichting mocht beschouwen. ${ }^{224}$

Art. $155 \mathrm{~Sv}$. dat toepasselijk is in politie- en correctionele zaken, bepaalt dat de getuigen ter rechtszitting, op straffe van nietigheid, de eed doen dat zij de gehele waarheid en niets dan de waarheid zullen zeggen. Art. 317, eerste lid, Sv. dat toepasselijk is in assisenzaken, bepaalt dat de getuigen, alvorens te getuigen, op straffe van nietigheid de eed afleggen dat zij zullen spreken zonder haat en zonder vrees, dat zij de gehele waarheid en niets dan de waarheid zullen zeggen. Deze eedformules worden uitgesproken in de wet bepaalde bewoordingen zonder wijzigingen of weglatingen. ${ }^{225}$ Overtreding van dit voorschrift heeft nietigheid tot gevolg. Wel is het zo dat overeenkomstig art. 407, derde lid, Sv. de nietigheid van een onregelmatige eed is gedekt, wanneer een ander vonnis of arrest op tegenspraak dan waarin een maatregel van inwendige aard wordt gelast, gewezen is zonder dat de nietigheid door een der partijen is aangevoerd of door de rechter ambtshalve is uitgesproken. ${ }^{226}$

De eed wordt normaal afgelegd rechtsstaand met ontdekt hoofd en opgestoken rechterhand. Deze vormen zijn evenwel niet voorgeschreven op straffe van nietigheid. ${ }^{27}$ Overeenkomstig de niet-officieel gepubliceerde koninklijk besluiten van 9 juni $18 I 7^{228}$ en 26 oktober I8I8 - van de Hollandse tijd dus ${ }^{229}$ - mochten Israëlieten bij de eedaflegging het hoofd bedekt houden, d.w.z. dat ze hun keppeltje niet moesten afzetten. Dit houdt noodzakelijk in dat ze hun hoofddeksel ook mochten ophouden als toehoorder.

222. F. Hélie, Traité de linstruction criminelle, dl. III, Bruylant-Christophe et C $\mathrm{C}^{\mathrm{ie}}$, Bruxelles, I869, nr. 4999.

223. Cass., 28 mei en 25 juni I867, Pas. I867, I, 275., concl. M. Leclercq.

224. Répertoire pratique du droit belge, Bruxelles-Paris, Bruylant-Librairie générale de droit, I95I, T. XII, tw. 'Serment', nr. I-I4.

225. Cass., 9 augustus I92I, Pas. I922, I, II; Cass. I2 juni I950, Pas. I950, I, 720.

226. Cass. P.02.0144.F, 20 maart 2002, www.cass.be; Pas. 2002, afl. 3, 76o, concl. J. Spreutels, J.; Rev. dr. pén. 2002, afl. 9-Io, 960, concl. J. Spreutels; Cass P.04.028I.F, I6 juni 2004, www.cass.be; J.L.M.B. 2004, II37 en http://jlmbi.larcier.be; Pas. 2004, I053; Rev. dr. pén. 2005, Io6; T. Strafr. 2005, 277, noot S. Vandromme, 'Verstek en het Hof van Assisen: de cassatie-arresten van 2 oktober 2002 en I6 juni 2004'.

227. Cass. 26 februari igoo, Pas. I900, I, I66.

228. J.S.G. Nypels, Législation criminelle, dl. II, Bruylant-Christophe et $\mathrm{C}^{\mathrm{ie}}$, Bruxelles, 1869 , nr. 705.

229. Recueil de la législation générale en vigueur en Belgique, T. II, nr. 734. 


\subsubsection{Verschijning als partij}

Het behoort de rechter de personen te identificeren die voor hem als partij in persoon verschijnen. Naast het probleem van de identificatie is er dit van de noodzakelijke onmiddellijkheid bij de ondervraging van bijvoorbeeld de beklaagde. Een Nederlandse rechtbank oordeelde dat de nikaab die het volledige gelaat bedekt, het onmogelijk maakt om de houding en lichaamstaal waar te nemen. Dat klemde doordat het ging om een minderjarig kind waarmee de man als niet-verzorgende ouder omgang wenste en de vrouw zich daartegen verzette. De vrijheid van godsdienst gaat, volgens de rechter, niet zover dat dit meebrengt dat hij in de uitoefening van zijn ambt en de vervulling van zijn taak door partijen kan worden beperkt, zodat de regels van een zorgvuldige procesvoering zouden moeten wijken of onder druk komen te staan, omdat deze door partijen in plaats van door de rechter zelf naar believen zouden kunnen worden ingevuld. De rechter beschouwde de vrouw daarom als verstekmakend. Hij voegde eraan toe dat hij hiermede niet handelt in strijd met artikel 6 EVRM. Het is de vrouw zelf die door haar keuze de toegang tot de rechter blokkeert, althans de rechter wil dwingen tot een houding die zich niet verdraagt met zijn taakstelling. ${ }^{230} \mathrm{Er}$ is geen dergelijke Belgisch vonnis (ten aanzien van een beklaagde) bekend.

\subsection{Rechterlijke beoordeling}

Uit het Belgische straf- en strafprocesrecht kan men een aantal maximes afleiden:

I. Het culturele verweer is een zaak van alle partijen in het strafproces. De opdracht van het openbaar ministerie, de onderzoeksrechter en de strafrechter is evenwel niet dezelfde als die van de beklaagde of de benadeelde. Zij hebben niet de strategische keuzemogelijkheid van deze partijen. ${ }^{23}{ }^{2}$ Zij kunnen niet naar goedvinden het culturele element achterwege laten of afzwakken, dan wel aanvoeren of benadrukken. Zij hebben integendeel de opdracht steeds de waarheid te achterhalen over misdrijf, dader en slachtoffer, naar die waarheid onbevangen recht te doen spreken of te spreken over het misdrijf, de zwaarte ervan en de rol van de beklaagde erbij, zijn onschuld of mate van schuld en ten slotte, als de beklaagde schuldig wordt bevonden, de bij de wet bepaalde straf of maatregel te eisen of toe te meten naar gelang de omstandigheden, onder meer de persoonlijke omstandigheden van de dader.

2. De magistraat die vaststelt dat in de strafzaak een cultureel element aan bod komt, heeft de ambtsplicht hierover de nodige informatie te doen inwinnen. Eventueel kan hij een cultuurspecialist of een cultureel-antropoloog als deskundige aanstellen om zich te doen voorlichten betreffende het culturele aspect. Dit schijnt in België nog niet vaak te gebeuren.

230. Rb. Zwolle (Ned.) Io oktober 2003, RABG 2003, afl. I8, I084, noot F. Petillon, 'De Niqaab-zaakVrouwe Justitia in negatief?'

23I. Zie i.v.m. de strategische verdedigingskeuze: K. Karakaya, 'Ik moest mijn namus, mijn eer redden!' De verdediging in eerwraakzaken, Wetenschapswinkel Rechten, Universiteit Utrecht, 2006, inzonderheid hfdst. 5 . 
3. De strafwet verbiedt en bestraft bepaalde culturele gewoonten en gebruiken. Sommige misdrijfomschrijving of bestraffingregels bevatten een cultureel element. Het kan bepalend zijn bij het vaststellen van de gerechtelijke waarheid en bij beoordeling van misdrijf, schuld en straf. De magistraat moet dus soms het culturele element beoordelen. Anderzijds moet hij zich hoeden voor algemene uitspraken over de waarde van vreemde culturen, maar dient hij integendeel zoveel mogelijk de gewetensvrijheid van de beklaagde of de benadeelde eerbiedigen.

Deze stelregels mogen het besluit zijn. 